Article

\title{
Anemonia sulcata and Its Symbiont Symbiodinium as a Source of Anti-Tumor and Anti-Oxidant Compounds for Colon Cancer Therapy: A Preliminary In Vitro Study
}

\author{
Laura Cabeza ${ }^{1,2,3}$, Mercedes Peña 1,2,3® , Rosario Martínez ${ }^{4}{ }^{(}$, , Cristina Mesas ${ }^{1,2,3}$, Milagros Galisteo ${ }^{5}$, \\ Gloria Perazzoli ${ }^{1,2,3}$, Jose Prados ${ }^{1,2,3, *}$, Jesús M. Porres ${ }^{4,+}$ and Consolación Melguizo $1,2,3,+(\mathbb{C}$ \\ 1 Institute of Biopathology and Regenerative Medicine (IBIMER), Center of Biomedical Research (CIBM), \\ University of Granada, 18100 Granada, Spain; lautea@ugr.es (L.C.); mpenacontreras@ugr.es (M.P.); \\ cristinam@correo.ugr.es (C.M.); gperazzoli@ugr.es (G.P.); melguizo@ugr.es (C.M.) \\ 2 Department of Anatomy and Embryology, Faculty of Medicine, University of Granada, 18071 Granada, Spain \\ 3 Biosanitary Institute of Granada (ibs.GRANADA), SAS-University of Granada, 18014 Granada, Spain \\ 4 Institute of Nutrition and Food Technology (INyTA), Biomedical Research Center (CIBM), \\ Department of Physiology, University of Granada, 18100 Granada, Spain; rosariomz@ugr.es (R.M.); \\ jmporres@ugr.es (J.M.P.) \\ 5 Department of Pharmacology, School of Pharmacy, University of Granada, 18071 Granada, Spain; \\ mgalist@ugr.es \\ * Correspondence: jcprados@ugr.es

Citation: Cabeza, L.; Peña, M.; Martínez, R.; Mesas, C.; Galisteo, M.; Perazzoli, G.; Prados, J.; Porres, J.M.; Melguizo, C. Anemonia sulcata and Its Symbiont Symbiodinium as a Source of Anti-Tumor and Anti-Oxidant Compounds for Colon Cancer Therapy: A Preliminary In Vitro Study. Biology 2021, 10, 134. https://doi.org/10.3390/ biology10020134

Academic Editors: Hang Fai Kwok and Claudio Luparello

Received: 29 December 2020

Accepted: 4 February 2021

Published: 8 February 2021

Publisher's Note: MDPI stays neutral with regard to jurisdictional claims in published maps and institutional affiliations.

Copyright: () 2021 by the authors. Licensee MDPI, Basel, Switzerland. This article is an open access article distributed under the terms and conditions of the Creative Commons Attribution (CC BY) license (https:// creativecommons.org/licenses/by/ $4.0 /)$.
Simple Summary: Colorectal cancer is one of the most frequent types of cancer in the population. Recently, invertebrate marine animals have been investigated for the presence of natural products which can damage tumor cells, prevent their spread to other tissues or avoid cancer develop. We analyzed the anemone Anemonia sulcata with and without the presence of its microalgal symbiont (Symbiodinium) as a source of bioactive molecules for the colorectal cancer therapy and prevention. Colon cancer tumor cells were exposed to Anemone extracts observing a remarkable cell death and a great antioxidant capacity. These preliminary results support that Anemonia sulcata could be a source of bioactive compounds against colorectal cancer and that the absence of its symbiont may enhance these properties. Further studies will be necessary to define the bioactive compounds of Anemonia sulcata and their mechanisms of action.

Abstract: Recently, invertebrate marine species have been investigated for the presence of natural products with antitumor activity. We analyzed the invertebrate Anemonia sulcata with $(\mathrm{W})$ and without $(\mathrm{W} / \mathrm{O})$ the presence of its microalgal symbiont Symbiodinium as a source of bioactive compounds that may be applied in the therapy and/or prevention of colorectal cancer (CRC). Animals were mechanically homogenized and subjected to ethanolic extraction. The proximate composition and fatty acid profile were determined. In addition, an in vitro digestion was performed to study the potentially dialyzable fraction. The antioxidant and antitumor activity of the samples and the digestion products were analyzed in CRC cells in vitro. Our results show a high concentration of polyunsaturated fatty acid in the anemone and a great antioxidant capacity, which demonstrated the ability to prevent cell death and a high antitumor activity of the crude homogenates against CRC cells and multicellular tumor spheroids, especially $\mathrm{W} / \mathrm{O}$ symbiont. These preliminary results support that Anemonia sulcata could be a source of bioactive compounds with antioxidant and antitumor potential against CRC and that the absence of its symbiont may enhance these properties. Further studies will be necessary to define the bioactive compounds of Anemonia sulcata and their mechanisms of action.

Keywords: Anemonia sulcata; Symbiodinium; antioxidant activity; antitumor activity; colorectal cancer 


\section{Introduction}

Marine ecosystems, the world's main reservoir of biodiversity and a relevant source of marine natural products (MNPs), are providing a large number of compounds with antitumor, antibacterial, antiviral and anti-inflammatory properties, among others [1-5]. Specifically, some marine organisms such as algae and animals are a source of products with anticancer activity which have been tested as a new or adjuvant treatment [6-8]. In this context, advanced colorectal cancer (CRC) lacks therapeutic options, requiring new strategies and drugs to improve its prognosis. CRC, the second most lethal cancer worldwide [9], is currently treated with conventional chemotherapy, which shows low tumor specificity and high toxicity in healthy tissues. In addition, the frequent development of multidrug resistance (MDR) phenotypes reduces the effectiveness of this treatment. Accordingly, MNPs may play a fundamental role in the discovery of new drugs to improve the prognosis of advanced CRC patients [10].

In this regard, research in the marine world has provided new chemical structures with potent antitumor efficacy, but whose mechanisms of action and molecular targets remain unknown in most cases [11-14]. In fact, eight MNPs have been approved for clinical use (five as anti-tumor drugs), and 38 are being tested in clinical trials [11]. In addition, marine organisms have provided components with antioxidant activity (e.g., terpenoids, tannins, ageloline A, flavonoids, alkaloids and saponins) $[12,15]$ which showed positive effects in cancer prevention [16-19]. Within marine invertebrates, the cnidarians (such as jellyfish, sea anemones and corals) have attracted increasing research interest in recent years [20-22]. Anemonia sulcata, a cnidarian (phylum Cnidaria) of the Actiniidae family, widespread in the Mediterranean and eastern Atlantic, produces various secondary metabolites and toxins to capture prey and defend itself from predation $[23,24]$. Although most of these molecules have been poorly described biologically, it is known that the main toxins act as blockers of voltage-dependent sodium and potassium channels $[25,26]$. Anemonia sulcata specimens have a symbiotic relationship with photosynthetic dinoflagellate microalgae of the genus Symbiodinium commonly known as zooxanthellae [27], which gives them a great competitive advantage. This association can be interrupted by a process called "bleaching", which results from exposure of these organisms to adverse conditions such as high temperatures, high light intensity or darkness. Bleaching leads to several changes at a physiological level that may alter the generation of metabolites [28]. Previous studies have described anti-tumor and anti-angiogenic activity in extracts from anemones and the presence of antioxidant enzymes involved in the maintenance of the symbiotic relationship. In fact, three of four protein fractions with low molecular weight obtained from Anemonia viridis showed cytotoxic activity in several human tumor cell lines (PC3, PLC/PRF/5 and A375) [29]. Moreover, a protein fraction from Anemonia viridis at a very low concentration $(14 \mathrm{nM})$ demonstrated anti-angiogenic activity in Human Microvascular Endothelial Cells (HMEC). The active principle responsible for this activity was a Kuntiz type inhibitor [30]. On the other hand, aqueous extracts of Actinica equina and Anemonia sulcata, which contained the alkaloid homarine, demonstrated antiproliferative activity in the RAW-264.7 cell line (murine macrophage) and human gastric adenocarcinoma cells via the activation of caspase-3 [24]. Besides, Anemonia viridis showed significant antioxidant activity through the presence of glutathione peroxidase and catalase in high concentrations [31,32].

The aim of our study was to analyze the invertebrate Anemonia sulcata with (W) and without $(\mathrm{W} / \mathrm{O})$ its microalgal symbiont Symbiodinium to determine if the bleaching process induces physiological changes that intensify the production of bioactive compounds with antitumor and antioxidant properties. These metabolites could be applied as a new strategy in the treatment and/or prevention of CRC to improve the prognosis of these patients. 


\section{Materials and Methods}

\subsection{Chemicals, Cell Lines and Animals}

The trichloroacetic acid, $\mathrm{NaOH}, \mathrm{Na}_{2} \mathrm{CO}_{3}, \mathrm{H}_{2} \mathrm{O}_{2}, 3-(4,5-D i m e t h y l t h i a z o l-2-y l)-2,5-$ Diphenyltetrazolium Bromide (MTT), dimethyl sulfoxide (DMSO), pepsin, pancreatin, proteases from Bacillus licheniformis and Aspergillus oryzae, bile salts, gallic acid, FolinCiocalteu reagent, Coomassie brilliant blue R250, Bradford Reagent and 2,2'-Azino-bis(3ethylbenzothiazoline-6-sulfonic acid) (ABTS) were purchased from Sigma-Aldrich; Thermo Scientific ${ }^{\mathrm{TM}}$ PageRuler ${ }^{\mathrm{TM}}$ Plus Prestained Protein Ladder from Thermo Fisher Scientific; absolute ethanol and $\mathrm{HCl}$ from Panreac; PI/RNase solution and Annexin V FITC apoptosis detection kit from Immunostep; Cell Counting Kit-8 (CCK-8) from Dojindo Laboratories; and Biotech RC Dialysis Membranes from Repligen.

The cell lines used from human colorectal cancer T84, SW480, HT29 and HCT15 were purchased from the American Type Culture Collection (ATCC, USA). The human no-tumor colon cell line CCD18 was obtained from the Centre for Scientific Instrumentation of the University of Granada (CIC-UGR, Spain). The murine cell line of colorectal cancer MC38 was kindly provided by Dr. J. Scholl (Public Health Service, National Institutes of Health, Bethesda, MD, USA). All the cell lines were cultured with Dulbecco's Modified Eagle's Medium (DMEM) (Sigma-Aldrich, St. Louis, MO, USA) supplemented with $1 \%$ of an antibiotics mixture (penicillin $=10.000 \mathrm{U} / \mathrm{mL}$ and streptomycin $=10 \mathrm{mg} / \mathrm{mL}$ ) (SigmaAldrich) and with $10 \%$ heat-inactivated fetal bovine serum (Thermo Fisher Scientific, Waltham, MA, USA) in a humidified atmosphere at $37^{\circ} \mathrm{C}$ and $5 \% \mathrm{CO}_{2}$. The Anemonia sulcata, animals with (W) and without (W/O) its microalgal symbiont Symbiodinium, were obtained from the company iMare Natural S.L.

\subsection{Proximate Composition and Fatty Acid Profile}

Four lyophilized specimens were used for the proximal composition analyses. Moisture content analysis were performed by the calculation of weight loss in the lyophilization process. Incineration in an oven at $550{ }^{\circ} \mathrm{C}$ was carried out for the determination of ashes by gravimetry as a measure of total mineral content. The protein content was analyzed by Kjeldahl's method, using 6.25 as a conversion factor. In addition, fat analysis was made by Soxhlet method after an acid hydrolysis. Finally, the fatty acid profile was analyzed by gas chromatography following the protocol of Martínez et al., [33].

\subsection{Anemonia sulcata Crude Extract Preparation $W$ and $W / O$ the Symbiont}

Two complete frozen animals $(2 \times \mathrm{W}$ and $2 \times \mathrm{W} / \mathrm{O})$ were thawed, lightly washed with water, weighed ( 18-18.5 g) and cut with scissors. After that, animals were mechanically homogenized with a high-speed homogenizer (IKA T10 Basic ULTRA-TURRAX9) followed by sonication at $50 \%$ power for $1 \mathrm{~min}$ in cycles of $30 \mathrm{~s}$ in a phosphate buffer $(50 \mathrm{mM}$ and $\mathrm{pH}$ 7.2). This process was done at $4{ }^{\circ} \mathrm{C}$. A volume of $20 \mathrm{~mL}$ was reserved for in vitro digestion (see below). Another volume of $10 \mathrm{~mL}$ was centrifuged 12,000 rpm for $15 \mathrm{~min}$ at $4{ }^{\circ} \mathrm{C}$ to remove tissue debris. After the centrifugation the supernatant was collected and used for in vitro studies with cultured cells.

\subsection{Ethanolic Extraction of Anemonia sulcata $W$ and $W / O$ the Symbiont}

Four complete frozen animals $(4 \times \mathrm{W}$ and $4 \times \mathrm{W} / \mathrm{O})$ were lyophilized and $0.5 \mathrm{~g}$ per replicate of the lyophilized samples was used to make the ethanolic extraction. A modified methodology of Kapravelou et al. was used [34]. A volume of $15 \mathrm{~mL}$ of a solution of absolute ethanol, $12 \mathrm{~N} \mathrm{HCl}$ and double-distilled water (50:0.25:50) was added to the sample and the mixture was stirred and sonicated 4 to 5 cycles of $10 \mathrm{~s}$. Nitrogen was then bubbled into the samples to avoid oxidation, and, at $\mathrm{pH} 2$, the samples were extracted for $30 \mathrm{~min}$. After that, the samples were centrifuged $(3500 \mathrm{rpm} / 10 \mathrm{~min}$ ) and the supernatant collected. With the pellet the complete extraction was made again in $10 \mathrm{~mL}$ of the previous solution. All the processes were made at $4{ }^{\circ} \mathrm{C}$. An aliquot of the supernatant was kept at $-20{ }^{\circ} \mathrm{C}$ for 
antioxidant experiments and other part was evaporated under vacuum to eliminate the ethanol and tolerate its use in cultured cells.

\subsection{Anemone Protein Hydrolysates}

The anemone protein hydrolysate (PH) was prepared from crude homogenates by an alkaline water extraction and hydrolysis process with protease treatment. A volume of $40 \mathrm{~mL}$ of distilled water was added to $9 \mathrm{~mL}$ of sample and heated to $33^{\circ} \mathrm{C}$ under continuous stirring for $30 \mathrm{~min}$. The $\mathrm{pH}$ was adjusted to 8.8 with $3 \mathrm{~N} \mathrm{KOH}$. The sample was centrifuged $7000 \mathrm{rpm}$ for $5 \mathrm{~min}$. The supernatant was reserved and the pellet was used to repeat the extraction. The two supernatants obtained were mixed and heated to $47^{\circ} \mathrm{C}$ for 20 min under continuous stirring and $500 \mu \mathrm{L}$ of $\mathrm{CaCl}_{2}$ and $\mathrm{MgSO}_{4} 100 \mathrm{mM}$ were added and the mixture incubated at $47^{\circ} \mathrm{C}$ for $20 \mathrm{~min}$. After that, enzymatic digestion began with the addition of protease from Bacillus licheniformis ( $0.3 \mathrm{AU} / \mathrm{g}$ protein) at $47^{\circ} \mathrm{C}$ and $\mathrm{pH} 8.8$ for $30 \mathrm{~min}$. Then, protease from Aspergillus oryzae was added (100 AU/g protein) using the same conditions. After the hydrolysis process, the sample was lyophilized and prior to be added to cell cultures, the lyophilized extract was resuspended in double-distilled water and heated $10 \mathrm{~min}$ at $95^{\circ} \mathrm{C}$ to inactivate the proteolytic enzymes.

To ensure that protease treatment was successful, the samples were analyzed by sodium dodecyl sulfate-polyacrylamide gel electrophoresis (SDS-PAGE) and Coomassie brilliant blue staining. Briefly, the protein content of the samples was measured by Bradford assay and equal amounts of protein $(35 \mu \mathrm{g})$ were loaded in each line of the gel (final concentration of acrylamide in the running gel: $15 \%$ ). Crude homogenates were used as control. Molecular weight markers from 10 to $250 \mathrm{kDa}$ were used. Lastly, gels were fixed and stained with Coomassie brilliant blue R250.

\subsection{Mass Spectrophotometry Analysis}

A volume of $10 \mu \mathrm{L}$ of crude homogenates (HOMG) W and HOMG W/O was used for the mass spectrophotometry analysis that was made with ultra-performance liquid chromatography (UPLC) (Acquity HClass, Waters) coupled to a quadrupole-time-of-flight (QTOF) mass spectrometer (Synap G2, Waters). The chromatographic conditions in [33] were used. The chromatograms were analyzed with MassLynx V4.1 software to tentatively identify compounds in the crude homogenates based on their mass fragments (MS) and retention times (RT) by the use of the Chemspider database.

\subsection{In Vitro Digestibility of the Crude Extracts}

The in vitro digestibility of crude homogenates $\mathrm{W}$ and $\mathrm{W} / \mathrm{O}$ symbiont was done according to Porres et al. (2005) with minor modifications [35]. Briefly, a volume of $36 \mathrm{~mL}$ of $0.01 \mathrm{~N} \mathrm{HCl}$ was mixed with $1.9 \mathrm{~mL}$ of each sample and $0.1 \mathrm{~N} \mathrm{HCL}$ was further added to the mixture until $\mathrm{pH} 2$ was reached. For the simulated gastric digestion, $10 \mathrm{~mL}$ of the former mixture were mixed with $10 \mathrm{~mL}$ of $0.01 \mathrm{~N} \mathrm{HCl}$ and $1 \mathrm{~mL}$ of $0.16 \mathrm{~g} / \mathrm{mL}(0.1 \mathrm{~N} \mathrm{HCl})$ pepsin and incubated in a shaking water bath at $37^{\circ} \mathrm{C}$ for $2 \mathrm{~h}$. Negative controls were made with the same volume of $0.01 \mathrm{~N} \mathrm{HCl}$ instead of the sample. Prior to the simulated intestinal digestion, a pH compensation step of 30 min was performed with $0.1 \mathrm{~N} \mathrm{NaHCO}_{3}$ added into the dialysis bags which were placed in the digestion vessels in a shaking water bath at $37^{\circ} \mathrm{C}$. Then, $5 \mathrm{~mL}$ of a $0.1 \mathrm{~N} \mathrm{NaHCO}_{3}$ solution with pancreatin $(4 \mathrm{mg} / \mathrm{mL})$ and bile salts $(25 \mathrm{mg} / \mathrm{mL})$ were added, and the was mixture incubated in a shaking water bath at $37^{\circ} \mathrm{C}$ for $2 \mathrm{~h}$. Once digestion was finished, the contents inside (sample dialyzed and potentially absorbable) and outside (sample retained that could reach the colon) the dialysis bags were collected and kept at $-20^{\circ} \mathrm{C}$ to be used in the following determinations. 


\subsection{Antioxidant Activity of the Samples}

\subsubsection{Quantification of Total Polyphenols}

This assay was performed by the use of a modified Folin-Ciocalteu colorimetric assay [36]. A volume of $125 \mu \mathrm{L}$ of diluted samples from crude homogenates, ethanolic extracts, protein hydrolysates, the in vitro digestion products or the standard solution of gallic acid $(0-600 \mathrm{mg} / \mathrm{L})$ was mixed with $500 \mu \mathrm{L}$ of double-distilled water and $125 \mu \mathrm{L}$ of Folin-Ciocalteu reagent. After $6 \mathrm{~min}$ of incubation, a solution of $1.25 \mathrm{~mL}$ of a $10 \%(w / v)$ $\mathrm{Na}_{2} \mathrm{CO}_{3} / 1 \mathrm{M} \mathrm{NaOH}$ was added, and the volume was made up with water to $3 \mathrm{~mL}$ and incubated for $90 \mathrm{~min}$. Then, after centrifugation ( $2000 \mathrm{rpm} / 2 \mathrm{~min}$ ), the optical density of the sample supernatant was measured at $750 \mathrm{~nm}$ (Multiskan ${ }^{\mathrm{TM}}$ FC Microplate Photometer, Thermo Fisher Scientific). The results were expressed as $\mu \mathrm{g}$ of gallic acid equivalent (GAE) per mg of sample.

\subsubsection{Free Radicals' Uptake/Retention (ABTS)}

This assay was performed based on the method of Miller et al. (1993), who used 2,2'Azino-bis(3-ethylbenzothiazoline-6-sulfonic acid) (ABTS) to measure the total antioxidant capacity of a fluid [37]. A volume of $6 \mu \mathrm{L}$ of the samples of crude homogenates, ethanolic extracts, protein hydrolysates and the in vitro digestion products or standard solution of gallic acid (0-60 mg/L) was mixed with $294 \mu \mathrm{L}$ of ABTS and incubated for $5 \mathrm{~min}$. After that, the optical density of the samples was measured at $620 \mathrm{~nm}$ (Multiskan ${ }^{\mathrm{TM}}$ FC, Microplate Photometer, Thermo Fisher Scientific). The blank was made with $6 \mu \mathrm{L}$ of water and $294 \mu \mathrm{L}$ of ABTS. The results were expressed as $\mu \mathrm{g}$ of gallic acid equivalent (GAE) per mg of sample.

\subsubsection{Antioxidant Activity in Cultured Cells}

To test the antioxidant activity in cultured cells, human colorectal cancer HT29 cell line was used. Cells were seeded in 96-well plates at a density of $5 \times 10^{4}$ cells/well in $150 \mu \mathrm{L}$ of supplemented DMEM. After $24 \mathrm{~h}$, the culture medium was replaced with serum-free DMEM. One day later, the treatments with crude homogenates, ethanolic extracts and protein hydrolysates were added at non-toxic concentrations of 0.5 and $0.05 \mu \mathrm{g} / \mathrm{mL}$ for $24 \mathrm{~h}$. Then, the medium that contained treatments was discarded, new fresh serum-free medium was added and some wells were treated with $\mathrm{H}_{2} \mathrm{O}_{2}$ in concentrations of 2.7 and $3 \mathrm{mM}$. After $6 \mathrm{~h}$, the medium was replaced again for fresh serum-free medium for $12 \mathrm{~h}$. Then, the MTT (3-(4,5-Dimethylthiazol-2-yl)-2,5-Diphenyltetrazolium Bromide) protocol was carried out. Briefly, $30 \mu \mathrm{L}$ of MTT was added per well for $4 \mathrm{~h}$ in culture conditions. Then, the medium was discarded, and $200 \mu \mathrm{L}$ of dimethyl sulfoxide (DMSO) plus $25 \mu \mathrm{L}$ of Sorensen's glycine buffer (glycine $0.1 \mathrm{M}, \mathrm{NaCl} 0.1 \mathrm{M}, \mathrm{pH}: 10.5$ with $0.1 \mathrm{NaOH}$ ) were added per well to dissolve formazan crystals. After $5 \mathrm{~min}$ of incubation at room temperature, the optical density of the wells was measured at $570 \mathrm{~nm}$ and a reference wavelength of $690 \mathrm{~nm}$ (Titertekmultiscan Colorimeter, Flow, Irvine) to determine the relative proliferation (\%RP) of treated cells.

\subsection{Antiproliferative Activity in CRC Cells}

The cell lines were seeded in 48-well plates at a density of $5 \times 10^{3}$ cells/well for T84, CCD18 and SW480 and HCT15, $15 \times 10^{3}$ cells/well for HT29 $3 \times 10^{3}$ cells/well for MC38 in $300 \mu \mathrm{L}$ of supplemented DMEM. The next day, treatments of crude homogenates (HOMG), heat-treated HOMG exposed to $96{ }^{\circ} \mathrm{C} / 5 \mathrm{~min}$ in a thermoblock or $56{ }^{\circ} \mathrm{C} / 30 \mathrm{~min}$ in a water bath, HOMG after 1-4 freeze-thaw cycles, two replicates of ethanolic extracts (ETOH), the $\mathrm{PH}$ and the digestion products from Anemonia sulcata $\mathrm{W}$ and $\mathrm{W} / \mathrm{O}$ symbiont were added in increasing concentrations. Negative control cells were untreated cells. After $72 \mathrm{~h}$, the MTT assay was performed to calculate the percentage of relative proliferation (\%RP) of cultures. 


\subsection{Cell Cycle and Apoptosis Assay}

Cell lines were seeded in 6-well plates at a density in cells/well of $7.5 \times 10^{4}$ for MC38 and SW480, $1 \times 10^{5}$ for T84 and CCD18 and $1.5 \times 10^{5}$ for HT29 and HCT15 in $2 \mathrm{~mL}$ of supplemented DMEM. The next day, the medium was discarded and replaced for the same quantity of serum-free DMEM to induce cell cycle arrest. After $24 \mathrm{~h}$, the medium was replaced again for supplemented DMEM and treatments with HOMG W and W/O symbiont at half-maximal inhibitory concentration $\left(\mathrm{IC}_{50}\right)$ for $48 \mathrm{~h}$ and the same treatments heated $\left(95^{\circ} \mathrm{C} / 5 \mathrm{~min}\right)$. After the incubation time elapsed, cells were detached, centrifuged (3000 rpm, $5 \mathrm{~min}$ ) and, for the cell cycle assay, fixed with 70\% ethanol-PBS $(900 \mu \mathrm{L}$ ) for $30 \mathrm{~min}$ at $4{ }^{\circ} \mathrm{C}$. After centrifugation, $500 \mu \mathrm{L}$ of PI/RNase solution were added to cells for $15 \mathrm{~min}$ at room temperature. For annexin V/PI staining, cells were washed with PBS and resuspended in $1 \times$ annexin binding buffer $\left(1 \times 10^{6}\right.$ cells $\left./ \mathrm{mL}\right)$ with $5 \mu \mathrm{L}$ of annexin V-FITC and PI according to manufacturer's instructions. After $15 \mathrm{~min}$ of incubation at room temperature in the darkness, $400 \mu \mathrm{L}$ of $1 \times$ annexin binding buffer were added. Finally, all samples were analyzed with FACScan (Becton Dickinson).

\subsection{Wound Healing Assay}

The cell line T84 was seeded in 12-well plates with $3 \times 10^{5}$ cells/well in $1 \mathrm{~mL}$ of culture medium. The next day the wound was made with a $100 \mu \mathrm{L}$ pipette tip followed by washing with PBS to remove the detached cells and adding serum-free medium $(1 \mathrm{~mL})$. Then, treatments with crude homogenates at a non-toxic dose, $\mathrm{IC}_{10}$ and $\mathrm{IC}_{30}$ were added for $72 \mathrm{~h}$. Every day, images were taken with an inverted light microscope Olympus CKX41 (Olympus Corporation) to observe the evolution of the wound closure. Cell migration was measured with MRI_Wound_Healing_Tool of ImageJ software and relative wound area (\%) was determined in relation to $0 \mathrm{~h}$ of exposition.

\subsection{Multicellular Tumor Spheroids Antitumor Assay}

To generate multicellular tumor spheroids (MTS), $50 \mu \mathrm{L}$ of $1 \%$ agarose $(w / v)$ were added to 96-well plates. Once agarose was gelled, $250 \mathrm{MC} 38$ cells/well were seeded in $200 \mu \mathrm{L}$ of supplemented DMEM and the plate was centrifuged $(800 \times \mathrm{g} / 5 \mathrm{~min})$. After $72 \mathrm{~h}$, the MTS were formed and in this moment were treated with HOMG W and W/O symbiont at $\mathrm{IC}_{50}, 2 \times \mathrm{IC}_{50}$ and $4 \times \mathrm{IC}_{50}$ doses for 3 days. Every day from the beginning of treatment, MTS volume was measured by light microscope images analyzed with ImageJ software. At the end of the exposure time cell proliferation was tested with the Cell Counting Kit-8 (CCK-8). Briefly, CCK-8 was added to each well to reach a final concentration of $10 \%$. After $4 \mathrm{~h}$ of incubation, optical density of the wells was measured at $450 \mathrm{~nm}$ and a reference wavelength of $620 \mathrm{~nm}$ (Titertekmultiscan Colorimeter, Flow, Irvine) to determine the relative proliferation (\%RP) of MTS.

\subsection{Statistical Analysis}

All results were expressed as the mean \pm standard deviation (SD). Statistical analysis was performed by the Student's t-test and one-way ANOVA (SPSS v.15, SPSS, Chicago, USA). Values of $p<0.05$ were considered significant.

\section{Results and Discussion}

\subsection{Proximate Composition and Fatty Acid Profile}

Proximate composition analysis revealed a high percentage of water in the anemone, both with $(\mathrm{W})$ and without $(\mathrm{W} / \mathrm{O})$ its microalgal symbiont ( $87 \%$ and $89 \%$, respectively). In addition, a high content of protein ( $8 \%$ and $5 \%$, respectively) (Figure $1 \mathrm{~A})$, polyunsaturated (PUFA) and saturated fatty acids (SFA) (Figure 1B) was detected in both samples. However, Anemonia sulcata W/O its symbiont showed a higher percentage of PUFA (41.4\%) than Anemonia sulcata $\mathrm{W}$ its symbiont $(33.2 \%)$. The PUFA with the highest concentration was 5,8,11,14,17-eicosapentaenoic acid (EPA), which also showed higher levels in Anemonia sulcata $\mathrm{W} / \mathrm{O}$ its symbiont $(35.1 \% \mathrm{~W} / \mathrm{O}$ versus $29.7 \% \mathrm{~W})$. Furthermore, the presence of 
oleic acid was similar in both samples $(9.8 \% \mathrm{~W} / \mathrm{O}$ and $8.5 \% \mathrm{~W})$ and the concentrations of arachidonic acid were almost undetectable. Fatty acid analysis suggested an added nutritional value of Anemonia sulcata W/O its symbiont based on its higher percentage of PUFA. In addition, the presence in both samples (especially in W/O) of EPA, a fatty acid with protective activity against CRC [38], could warrant its preventive application in this pathology. In fact, the presence of PUFA (n-6 PUFA, EPA and DHA) in the diet has been correlated with a significant decrease in digestive cancer risk, which may be regulated by the ingestion of vegetables, fruits, vitamin $C$ and fiber [39]. Moreover, PUFAs not only have a protective effect in CRC but also improve its treatment by increasing the activity of antioxidant enzymes, reducing lipid peroxidation and inhibiting harmful derivatives of arachidonic acid, thus warranting their use as adjuvants in radio and chemotherapy [40]. In relation to this last point, the absence of arachidonic acid-which is associated with an increased risk of CRC [38] —in the anemones, both with $(\mathrm{W})$ and without (W/O) its microalgal symbiont, reinforces our hypothesis.

A)

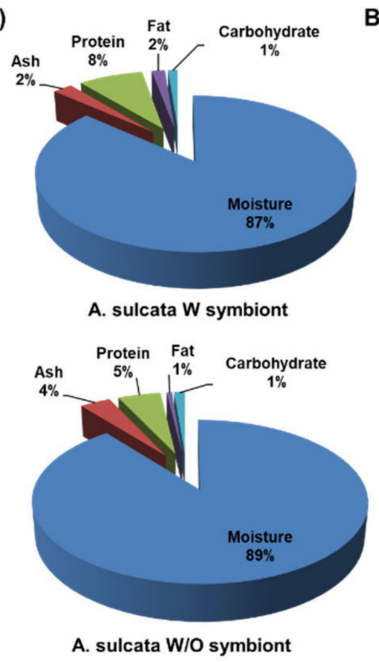

B)

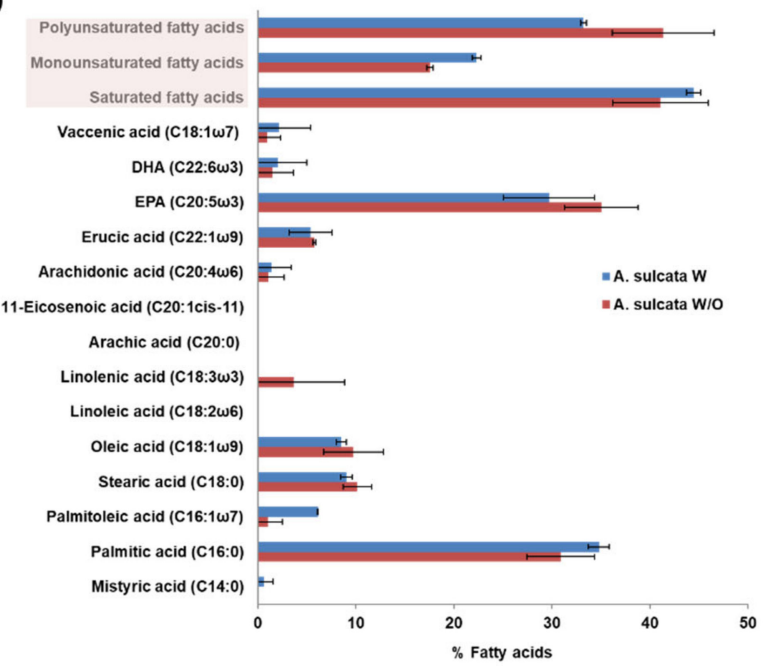

Figure 1. Composition of Anemonia sulcata with (W) and without (W/O) its microalgal symbiont Symbiodinium. (A) Graphical representation of the proximate composition. (B) Graphical representation of the fatty acids. The sum of saturated, monounsaturated and polyunsaturated fatty acids is highlighted in the pink box. DHA and EPA are cis-4,7,10,13,16,19-docosahexaenoic acid and 5,8,11,14,17-eicosapentaenoic acid, respectively. Data are represented as the mean \pm standard deviation of duplicate samples.

\subsection{Anemone Protein Hydrolysates}

SDS-PAGE was performed to ensure that the enzymatic digestion was successful and to observe differences in the pattern of proteins between the crude homogenates. This procedure caused changes in the pattern of proteins in the PHs compared to the crude homogenates (Figure 2). In the case of PHs, a reduction in the number of main protein bands and in their density compared to the crude homogenates was observed, indicating proteolysis of large proteins. This reduction was similar in the samples $\mathrm{W}$ and $\mathrm{W} / \mathrm{O}$ symbiont. 


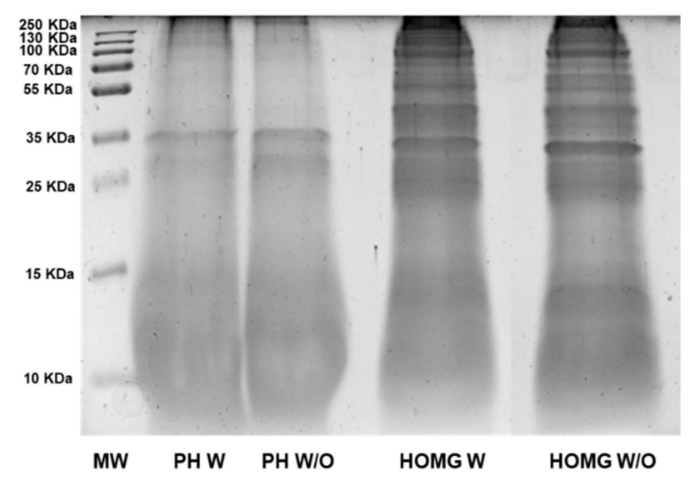

Figure 2. SDS-PAGE of proteins from Anemonia sulcata with (W) and without (W/O) its microalgal symbiont Symbiodinium. The protein hydrolysates were compared to the crude homogenates to observe different patterns of proteins, indicating that the enzymatic digestion had been carried out correctly. Molecular weight (MW); protein hydrolysates (PH); crude homogenates (HOMG).

\subsection{Mass Spectrophotometry Analysis}

Chromatograms from the mass spectrophotometry analysis of the crude homogenates of Anemonia sulcata (Figure 3) were analyzed to detect possible bioactive substances. From the tentative compounds (Table 1), gadusol; neogambogic acid; casearupestrin A and B; olivoretin A, B, C and E; and ophioxanthol were present in both HOMG W and W/O symbiont. Interestingly, gadusol and ophioxanthol have been previously described in other marine organisms. Gadusol blocks UV radiation, showing photoprotective and antioxidant activities [41]. Ophioxanthin is a carotenoid sulfate from Ophioderma longicaudum [42]. The carotenoid family has widely demonstrated antioxidant activity as a scavenger of $\mathrm{ROX}, \mathrm{O}_{2}$ and peroxyl radicals, as well as antitumor activity and protective effects (cancer chemoprevention) in cancer development [43]. Furthermore, 1-arachidonoylglycerone 3phosphate was detected in HOMG W, although no function has been previously described for this compound. The presence of some of these compounds in the crude homogenates from Anemonia sulcata could be the cause of the observed activities that will be discussed in the following sections.

A)

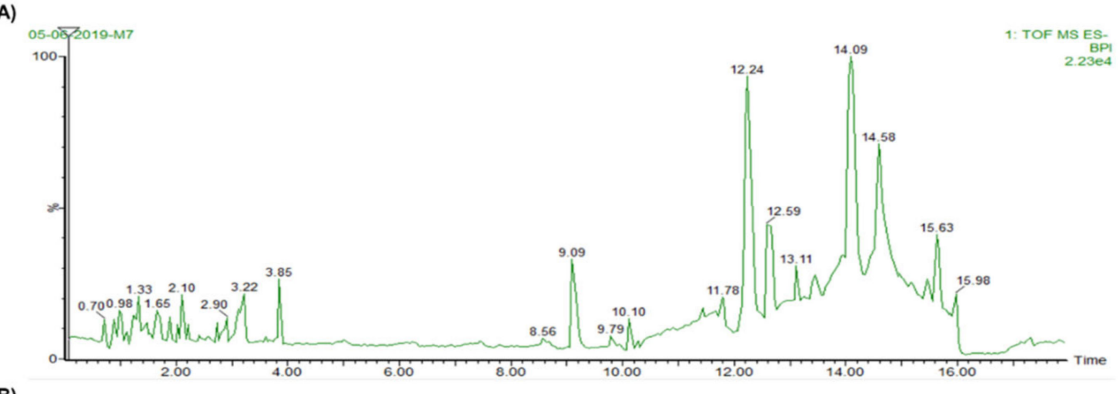

B)

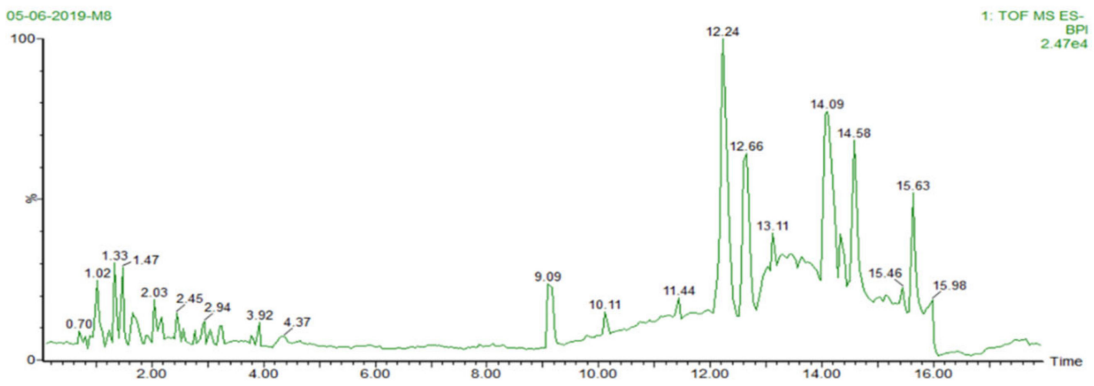

Figure 3. Chromatograms of the crude homogenates from Anemonia sulcata with (A) and without (B) its symbiont. 
Table 1. Bioactive compounds (tentative identification) in the crude homogenates from Anemonia sulcata.

\begin{tabular}{|c|c|c|c|c|c|c|c|c|c|}
\hline \multicolumn{10}{|c|}{ HOMG W } \\
\hline RT & PPM & $\begin{array}{l}{[\mathrm{M}-} \\
\mathrm{H}]-\end{array}$ & MF & Compound & & MS Fragments & & $\begin{array}{l}\text { Biological } \\
\text { Activity }\end{array}$ & Ref. \\
\hline 0.98 & 2 & 203.056 & $\mathrm{C}_{8} \mathrm{H}_{12} \mathrm{O}_{6}$ & * Gadusol & 153.0464 & $1,369,942$ & 119.042 & Antioxidant & [41] \\
\hline 1.22 & -2.2 & 315.1225 & $\mathrm{C}_{18} \mathrm{H}_{20} \mathrm{O}_{5}$ & Combretastatin A-4 & 159.0089 & 151.0379 & 120.0161 & Antitumor & {$[44,45]$} \\
\hline 2.73 & 4 & 455.2217 & $\mathrm{C}_{23} \mathrm{H}_{37} \mathrm{O}_{7} \mathrm{P}$ & $\begin{array}{l}\text { * 1-Arachidonoylglycerone 3-phosphate } \\
\text { (arachidonic acid -ARA derived) }\end{array}$ & 267.0494 & 119.0465 & 112.9926 & Unknown & [46] \\
\hline 11.8 & -2.2 & 645.3082 & $\mathrm{C}_{38} \mathrm{H}_{46} \mathrm{O}_{9}$ & Neogambogic acid & 554.2553 & 553.3141 & 267.0923 & Antitumor & [47] \\
\hline 12.59 & -1 & 599.3214 & $\mathrm{C}_{34} \mathrm{H}_{48} \mathrm{O}_{9}$ & Casearupestrin A, B & 555.2526 & 373.0900 & 313.1264 & Antitumor & {$[48]$} \\
\hline 14.58 & 6 & 603.4449 & $\mathrm{C}_{40} \mathrm{H}_{60} \mathrm{O}_{4}$ & ${ }^{*}$ Ophioxanthol (carotenoid) & 347.2022 & 327.2592 & 301.2049 & Antioxidant & [42] \\
\hline \multicolumn{10}{|c|}{ HOMG W/O } \\
\hline RT & PPM & $\begin{array}{l}\text { [M- } \\
\mathbf{H}]-\end{array}$ & MF & Compound & & MS Fragments & & $\begin{array}{l}\text { Biological } \\
\text { Activity }\end{array}$ & Ref. \\
\hline 1.02 & 0 & 203.0556 & $\mathrm{C}_{8} \mathrm{H}_{12} \mathrm{O}_{6}$ & $\begin{array}{c}{ }^{*} \text { Gadusol } \\
\text { 2-(4-Cyclohexylphenyl)-2-oxoethyl }\end{array}$ & 173.0172 & 119.9808 & 112.9946 & Antioxidant & [41] \\
\hline 3.92 & -9.5 & 483.2489 & $\mathrm{C}_{32} \mathrm{H}_{36} \mathrm{O}_{4}$ & $\begin{array}{c}\text { 4-\{[4-(2-methyl-2-propanyl)phenoxy }] \\
\text { methyl\}benzoate }\end{array}$ & 239.0783 & 119.0519 & 112.995 & Unknown & - \\
\hline 14.09 & -9.9 & 464.3231 & $\mathrm{C}_{29} \mathrm{H}_{43} \mathrm{~N}_{3} \mathrm{O}_{2}$ & Olivoretin A, B, C, E & 377.2533 & 347.2082 & 267.0982 & Inactive & [49] \\
\hline 14.58 & 2.3 & 603.4427 & $\mathrm{C}_{40} \mathrm{H}_{60} \mathrm{O}_{4}$ & * Ophioxanthol (carotenoid) & 348.2070 & 301.2073 & 179.0856 & Antioxidant & [42] \\
\hline 15.63 & 3.1 & 835.5445 & $\mathrm{C}_{43} \mathrm{H}_{80} \mathrm{O}_{15}$ & $\begin{array}{c}\text { 3-\{[6-O- }(\alpha-\mathrm{D}-\text { Galactopyranosyl)- } \beta \text {-D- } \\
\text { galactopyranosyl]oxy\}-1,2-propanediyl } \\
\text { ditetradecanoate }\end{array}$ & 554.255 & 553.3211 & 347.2074 & Unknown & - \\
\hline
\end{tabular}




\subsection{In Vitro Digestibility}

After simulated gastric and intestinal digestion and intestinal absorption, the bioaccessible or dialyzed (DIAL) amount of HOMG W and HOMG W/O was $1 \pm 0.27$ and $1.17 \pm 0.42 \mathrm{mg}$ of dialyzed fraction/mL sample, respectively, while the fraction of the digested sample potentially dialyzable $(100 \%)$ was 1.5 and $1.75 \mathrm{mg} / \mathrm{mL}$, respectively. Thus, the percent dialyzed from the sample was $64.01 \pm 17.2 \%$ and $66.58 \pm 23.8 \%$ for HOMG W and HOMG W/O, respectively. Our results indicate that more than a half of the anemone digested in both samples was potentially bioavailable, suggesting that they could reach the tissues via the bloodstream and exert their antitumor and/or antioxidant effects [50,51]. However, non-dialyzable digestion products could conserve these activities after digestion and exert their effects in the colon.

\subsection{Antioxidant Activity of the Samples}

\subsubsection{Quantification of Total Polyphenols}

Total polyphenols content was measured in the crude homogenates from Anemonia sulcat $a$ and their digestion products. Ethanolic extracts and protein hydrolysates were obtained (see Sections 2.4 and 2.5) to carry out the same test. Total polyphenols content was similar in the crude homogenates $\mathrm{W}$ and $\mathrm{W} / \mathrm{O}$ symbiont (Table 2). The simulated digestion process decreased this polyphenols content in both samples, although the reduction was lower in HOMG W/O DIAL. This finding is in agreement with previous observations in extracts from brown seaweed (rich in phlorotannin), in which reduction in total polyphenols was observed after a simulated digestion [52]. Microencapsulation of the extracts has been used to overcome this limitation because it allows protecting them from the acidic environment and enzymatic activity of digestion, preserving its antioxidant activity [53]. On the other hand, the ethanolic extracts and protein hydrolysates only showed a slight decrease in the quantity of polyphenols compared to the crude homogenates. In fact, ethanolic extracts with the symbiont showed similar values to the crude homogenates (12.55 and $13.37 \mu \mathrm{g} \mathrm{GAE} / \mathrm{mg}$ sample for EXTOH W and HOMG W, respectively). Therefore, none of the extraction processes reduced the quantity of total polyphenols of the original specimen.

Table 2. Total polyphenols content of different samples obtained from Anemonia sulcata.

\begin{tabular}{lcc}
\hline & W Symbiont & W/O Symbiont \\
\hline HOMG & $13.37 \pm 0.59$ & $13.77 \pm 0.13$ \\
EXTOH & $12.55 \pm 0.19$ & $9.4 \pm 0.21$ \\
PH & $11.23 \pm 0.19$ & $9.31 \pm 0.52$ \\
CONTROL DIAL & $5.75 \pm 0.45$ & $5.87 \pm 0.6$ \\
CONTROL RET & $4.96 \pm 0.27$ & $6.17 \pm 0.53$ \\
HOMG DIAL & $7.26 \pm 0.8$ & $9.19 \pm 0.95$ \\
HOMG RET & $6.44 \pm 0.3$ & $7.75 \pm 0.38$
\end{tabular}

GAE, gallic acid equivalent (GAE). The results are expressed in $\mu \mathrm{g}$ GAE/mg sample as mean \pm standard deviation of two samples with four replicates. Crude homogenates (HOMG); ethanolic extracts (EXTOH); protein hydrolysate (PH); dialyzed and retained controls (CONTROL DIAL and CONTROL RET); dialyzed and retained homogenates (HOMG DIAL and HOMG RET); with and without symbiont (W and W/O).

\subsubsection{Assessment of Free Radicals' Uptake/Retention}

The uptake/retention of free radicals by the crude homogenates from Anemonia sulcata and their digestion products, ethanolic extracts and protein hydrolysates was analyzed using ABTS. As shown in Table 3, the crude homogenates $\mathrm{W}$ and $\mathrm{W} / \mathrm{O}$ the symbiont showed higher antioxidant capacity than their digestion products. In fact, Sun et al. (2019) described that $\mathrm{pH}$ conditions and digestive enzymatic activity may reduce the ability of ABTS radical scavenging of some substances [54]. Interestingly, samples of crude homogenates $\mathrm{W} / \mathrm{O}$ the symbiont and their dialyzed digestion products showed significantly higher capacity of uptake/retention of free radicals $(p<0.05)$. Conversely, the retained samples of the HOM $W$ symbiont showed a $\sim 2$-fold higher antioxidant capacity vs. W/O samples, although no significant differences were found. These results suggest 
that oral administration of HOMG W/O could be useful due to its antioxidant activity after digestion and dialyzability. However, the conserved antioxidant activity of the retained fraction could be modulated by other factors such as the intestinal microbiota [55]. Finally, analysis of the ethanolic extracts and protein hydrolysates showed that EXTOH $\mathrm{W} / \mathrm{O}$ preserved the antioxidant activity, whereas the EXTOH $\mathrm{W}$ reduced this activity in comparison with the crude homogenates. In addition, the protein hydrolysates W showed a greater antioxidant capacity (with a higher percent inhibition) compared to the rest of the extracts, and, therefore, a greater capacity for reactive oxygen species (ROS) uptake.

Table 3. Free radicals' uptake/retention of different samples obtained from Anemonia sulcata.

\begin{tabular}{lcc}
\hline & W Symbiont & W/O Symbiont \\
\hline HOMG & $4.71 \pm 0.13$ & $5.21 \pm 0.04$ \\
EXTOH & $1.97 \pm 0.04$ & $4.4 \pm 0.17$ \\
PH & $9.81 \pm 0.9$ & $4.53 \pm 0.2$ \\
CONTROL DIAL & $7.73 \pm 0.2$ & $8.66 \pm 0.42$ \\
CONTROL RET & $4.08 \pm 0.43$ & $6.59 \pm 0.69$ \\
HOMG DIAL & $0 \pm 0.51$ & $1.52 \pm 0.5$ \\
HOMG RET & $1.81 \pm 0.11$ & $0.83 \pm 0.14$ \\
\hline
\end{tabular}

GAE, gallic acid equivalent (GAE). The results are expressed in $\mu \mathrm{g} \mathrm{GAE} / \mathrm{mg}$ sample as mean \pm standard deviation of three replicates. Crude homogenates (HOMG); ethanolic extracts (EXTOH); protein hydrolysate (PH); dialyzed and retained controls (CONTROL DIAL and CONTROL RET); dialyzed and retained homogenates (HOMG DIAL and HOMG RET); with and without symbiont (W and W/O).

\subsubsection{Antioxidant Activity in Cultured Cells}

It is known that cnidarians, including Anemonia sulcata, produce high quantities of antioxidant enzymes (e.g., glutathione peroxidases) to eliminate ROS generated by their symbionts [32]. Moreover, the microalga Symbiodinium produces ROS in normal conditions. However, high temperatures, high solar illumination or light depletion may affect the symbiotic relationship [56,57], increasing ROS production and inducing overexpression of antioxidant mechanisms to survive. This situation is known as "coral bleaching". For example, a decrease in Symbiodinium photosynthesis (30-50\%) together with a reduction in superoxide dismutase activity and antioxidant activity of peridinin, diatoxanthin and the ubiquitin-proteasome pathway have been observed after bleaching $[57,58]$. In our case, it is possible that the light stress situation that was induced to inactivate the symbiont of Anemonia sulcata was able to trigger a greater production of ROS and, consequently, of antioxidant molecules. To determine the modulation of antioxidant activity by the crude homogenates, ethanolic extracts and protein hydrolysates from Anemonia sulcata, an assay with non-toxic doses in HT29 cells was carried out. $\mathrm{H}_{2} \mathrm{O}_{2}$ exposure was used as a positive control. As shown in Figure 4, both HOMG W and HOMG W/O induced a clear protective effect. In fact, all doses of HOMG W significantly increased the proliferation rate of HT29 cells $(p<0.05)$, highlighting the change observed between $\mathrm{H}_{2} \mathrm{O}_{2} 3 \mathrm{mM}(57.89 \%)$ and $\mathrm{H}_{2} \mathrm{O}_{2}$ $3 \mathrm{mM}+\mathrm{HOMG} \mathrm{W}$ at 0.05 and $0.5 \mu \mathrm{g} / \mathrm{mL}(86.88 \%$ and $91.81 \%$, respectively). Better results were obtained with $\mathrm{HOMG} W / \mathrm{O}$, which also increased this percentage between $\mathrm{H}_{2} \mathrm{O}_{2}$ $3 \mathrm{mM}(28.46 \%)$ and $\mathrm{H}_{2} \mathrm{O}_{2} 3 \mathrm{mM}+\mathrm{HOMG} \mathrm{W} / \mathrm{O}$ at 0.05 and $0.5 \mu \mathrm{g} / \mathrm{mL}(75.97 \%$ and $71.49 \%$, respectively). Thus, the antioxidant protective capacity was higher with the HOMG $\mathrm{W} / \mathrm{O}$ pre-treatment (\%RP increase up to 2.7 times) than with the HOMG W pre-treatment (\%RP increase up to 1.6 times). These results suggest that the greater antioxidant activity of the HOMG W/O compared to the HOMG W/O is related to the light stress phenomenon ("coral bleaching"). Finally, treatment with ethanolic extracts and protein hydrolysates did not induce any significant protective effect in HT29 cells. 


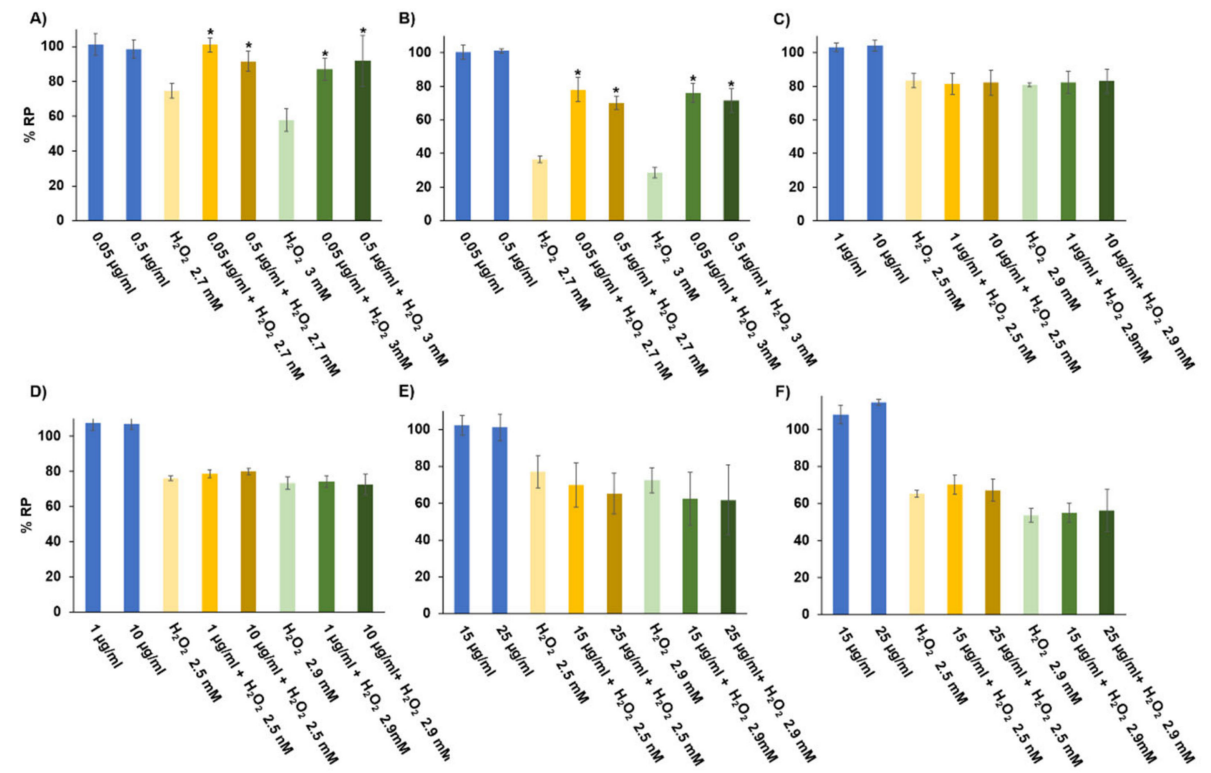

Figure 4. Antioxidant activity of Anemonia sulcata in cultured cells. The HT29 human CRC cell line was exposed to $\mathrm{H}_{2} \mathrm{O}_{2}$ and non-toxic doses of: crude homogenates with symbiont (W) (A); crude homogenates without symbiont W/O (B); ethanolic extract $\mathrm{W}(\mathbf{C})$; ethanolic extract $\mathrm{W} / \mathrm{O}(\mathbf{D})$; protein hydrolysate $\mathrm{W}(\mathbf{E})$; and protein hydrolysate W/O (F). Relative proliferation was obtained by the MTT protocol. Data are represented as the mean \pm standard deviation of octuplicate cultures. The symbol * indicates significant differences with $\mathrm{H}_{2} \mathrm{O}_{2}$ treatment.

\subsection{Antitumor Activity}

\subsubsection{Antiproliferative Effect in Cultured Cells}

Colon cells exposed to the crude homogenates showed that HOMG W/O caused a significantly higher cell death rate than HOMG W $(p<0.05)$. As shown in Figure 5, the HOMG $\mathrm{W}$ and $\mathrm{W} / \mathrm{O} \mathrm{IC}_{50}$ values were 7.78 and $2.36 \mu \mathrm{g} / \mathrm{mL}$ for $\mathrm{T} 84,17.84$ and $19.86 \mu \mathrm{g} / \mathrm{mL}$ for HT29, 40.76 and $13.02 \mu \mathrm{g} / \mathrm{mL}$ for HCT15 and 3.45 and $1.21 \mu \mathrm{g} / \mathrm{mL}$ for MC38, respectively. Minor $\mathrm{IC}_{50}$ differences were detected in CCD18 cells $(3.58$ and $2.81 \mu \mathrm{g} / \mathrm{mL}$, respectively). Only the SW480 colon cancer cell line did not show significant differences between the two treatments $(0.54 \mu \mathrm{g} / \mathrm{mL} \mathrm{W}$ and $1.09 \mu \mathrm{g} / \mathrm{mL} \mathrm{W} / \mathrm{O})$, although it was the most sensitive cell line to both treatments. In addition, the antiproliferative activity of both extracts was modulated by temperature. In fact, the crude homogenates exposed to high temperatures $\left(95\right.$ and $56^{\circ} \mathrm{C}$ ) or freeze-thaw cycles decreased their antitumor effect (Figure S3A,B). In the case of freeze-thaw cycles, this change correlated with the number of cycles, with loss of effect after four cycles (Figure S3C,D). These results suggest that those substances responsible for the antiproliferative activity, such as proteins, could be sensitive to temperature increase. Indeed, low concentrations $(14 \mathrm{nM})$ of the small protein BDS-5 obtained from Anemonia viridis can inhibit endothelial cell growth and angiogenesis [30]. Furthermore, a fraction (Fraction II) of low molecular weight proteins from Anemonia viridis inhibited the growth of A375, PLC/PRF/5 and PC3 cancer cells by apoptosis without affecting ROS or caspases [29]. An increase in protein content has been observed in samples from Entacmaea quadricolor (i.e., venom) after the bleaching process, with an increase in nematocysts production and in toxicity [59]. Similar changes could explain the different cell toxicity between HOMG W/O and HOMG W. On the other hand, we tested the antiproliferative activity of the ethanolic extracts and protein hydrolysates from Anemonia sulcata $\mathrm{W}$ and $\mathrm{W} / \mathrm{O}$ the symbiont. Interestingly, both samples showed a significant loss of antiproliferative effect in all colon cell lines (Figures S1 and S2 and Table S1). Finally, digestion products were also tested in tumor cells and showed no cell death with any treatment (Figure S4), indicating that the antitumor potential of the crude homogenates was not preserved after our simulated digestion. 

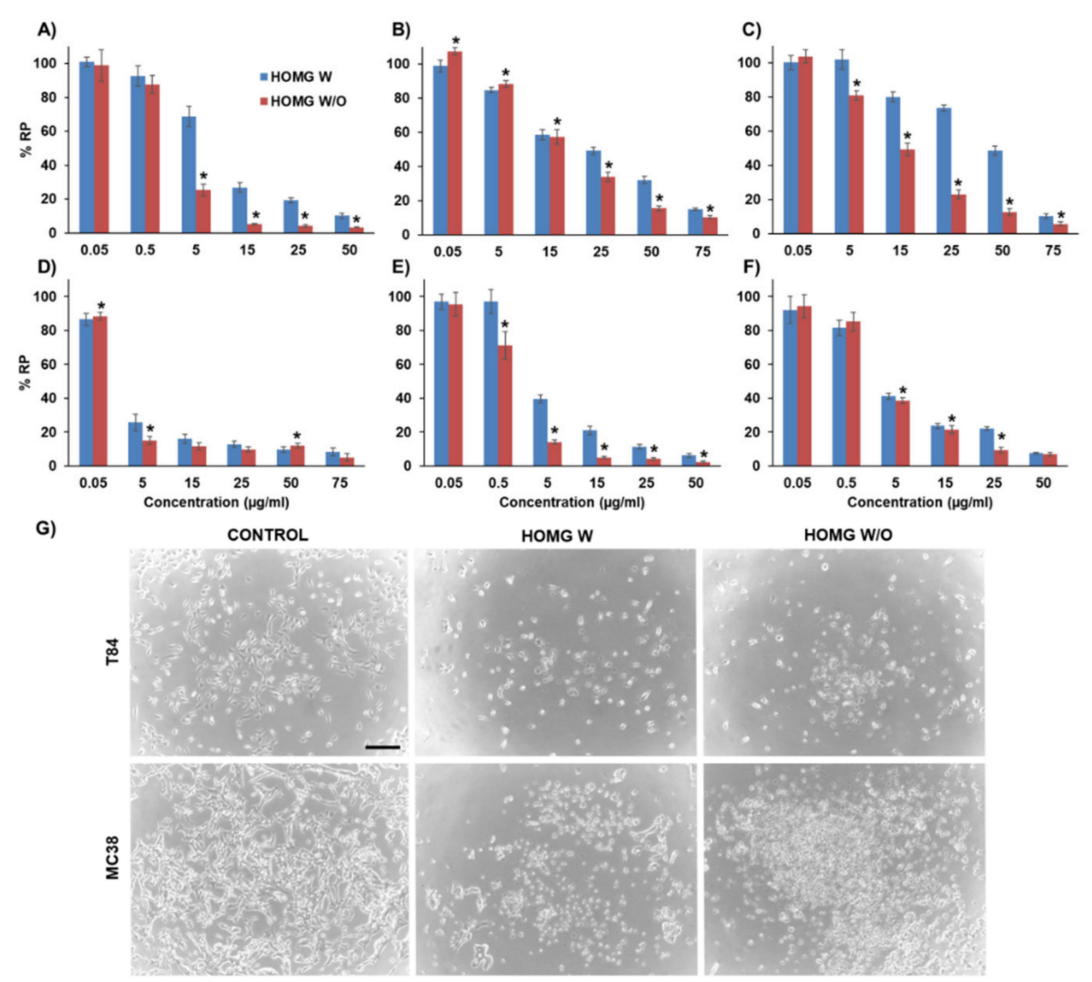

Figure 5. Antiproliferative activity of the crude homogenates in colon cells. T84 (A), HT29 (B), HCT15 (C) and SW480 (D) human colon cancer cells; MC38 murine colon cancer cell line (E); and CCD18 non-malignant human colon cell line (F) were exposed to the crude homogenates of Anemonia sulcata with $(\mathrm{W})$ and without $(\mathrm{W} / \mathrm{O})$ the microalgal symbiont Symbiodinium for $72 \mathrm{~h}$. Relative proliferation is expressed as \%RP. Data are represented as the mean \pm standard deviation of triplicate cultures. The symbol * indicates significant differences between crude homogenates with $(\mathrm{W})$ and without $(\mathrm{W} / \mathrm{O})$ symbiont. Microscopy images of T84 and MC38 colon cancer cells treated with $25 \mu \mathrm{g} / \mathrm{mL}$ of crude homogenates for $48 \mathrm{~h}(\mathrm{G})$. Control cells represent the untreated cells. The images were taken at $4 \times$ magnification (scale bar $=200 \mu \mathrm{m})$.

\subsubsection{Cell Cycle Assay}

The cell cycle assay revealed a decrease in the cell percentage in the G0/G1 phase with an increase in the G2/M and subG1 phases in some cell lines (HT29, HCT16 and MC38) compared to untreated cells (Figure 6A-E). Specifically, the reduction in the cell percentage in the G0/G1 phase was $10.85 \%$ and $12.1 \%$ in $\mathrm{HCT} 15$ and $5.5 \%$ and $5.9 \%$ in MC38, while the increase in the cell percentage in the subG1 phase was $23.3 \%$ and $21.3 \%$ in HCT15 and $1.9 \%$ in $\mathrm{MC} 38$ for HOMG $\mathrm{W}$ and $\mathrm{W} / \mathrm{O}$, respectively, with no significant differences between the crude homogenates. With the annexin V staining (Figure 6F,G), the crude homogenates reduced the percentage of living cells up to $84.19 \%$ and $56.47 \%$ for HOMG $\mathrm{W}$ and $\mathrm{W} / \mathrm{O}$, respectively, compared to control cells (95.4\%). Moreover, a significant increase $(p<0.05)$ in the number of cells in early apoptosis was observed $(12.45 \%, 28.01 \%$ and $1.96 \%$ for HOMG W, W/O and control, respectively) with a smaller increase in the cells in late apoptosis/dead (2.63\%, 13.18\% and 1.99\% for HOMG W, W/O and control, respectively). On the other hand, percentages not greater than $2.34 \%$ were observed in the group of necrotic cells for all treated and control cells. Finally, no significant differences were observed between the heated crude homogenates and control cells. As we observed previously, the exposure of the crude homogenates to high temperatures inhibited their cytotoxic effect. Therefore, the mechanism of cell death of the crude homogenates could be primarily mediated by apoptosis, with a decrease in the cells in the G0/G1 phase and an increase in the cells in the G2/M and subG1 phases, intensified by treatment with the anemone $\mathrm{W} / \mathrm{O}$ symbiont. Cell cycle analysis of the venom from the sea anemone Heteractis magnifica also showed an increase in the cells in the subG1 phase and a decrease in the G1 
phase in breast cancer cells (T47D and MCF7) compared to control cells. In addition, this anemone venom also activated caspases-3, -8 and -9 , revealing that tumor cell death was dependent on the apoptotic pathway [60]. The same anemone showed cell cycle arrest and cell death by apoptosis in the A549 lung cancer cell line, whereas cell death in non-tumor cells (MRC5) was caused by necrosis [61].
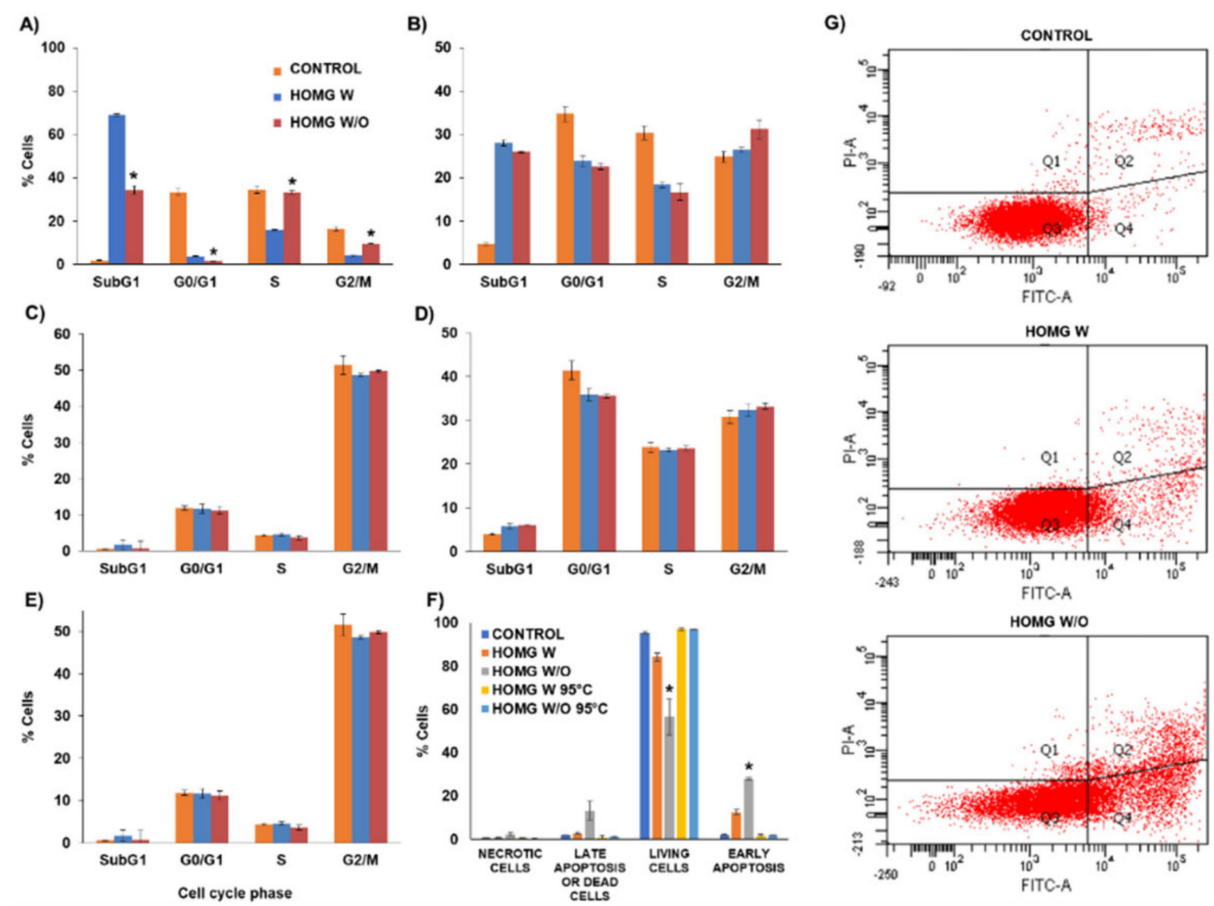

Figure 6. Modulation of cell cycle by the crude homogenates (HOMG) and cell death mechanism. (A) HT29; (B) HCT15; (C) SW480; (D) MC38; (E) CCD18; and (F) T84 cells were treated with HOMG $\mathrm{W}$ and $\mathrm{W} / \mathrm{O}$ symbiont at a dose equivalent to the $\mathrm{IC}_{50}$ value during $48 \mathrm{~h}$. Non-treated cells were used as negative controls. Results are expressed as the percentage of labeled cells in each cell cycle phase or type of cell death. (G) Images of flow cytometry results of T84 cells exposed to PI and annexin-V (Fluorescein, FITC). Data are represented as the mean value \pm standard deviation of duplicate cultures. The symbol * indicates significant differences between crude homogenates with (W) and without (W/O) symbiont.

\subsubsection{Wound Healing Assay}

To determine the activity of the homogenates over the migration capacity of the colon cancer cells, a wound healing assay was carried out. As shown in Figure 7A and Figure S5, HOMG both $\mathrm{W}$ and W/O did not modify cell migration at any of the tested doses. Therefore, although our homogenates showed a clear antiproliferative activity against colon cancer cells, they did not affect cell migration, suggesting no effect on the degree of tumor invasiveness. Some other marine invertebrates contain biological compounds with activity against tumor cell migration. For instance, peptides (CS5931) from the sea squirt Ciona savignyi inhibited tumor invasiveness through enolase 1 [62]. In addition, dieckol from Ecklonia cava, frondoside A from Cucumaria frondosa, geodiamolide $\mathrm{H}$ from Geodia corticostylifera and pachycladins A-E from Cladiella pachyclados demonstrated a similar activity [63]. In contrast, toxin ATX II from Anemonia Viridis, enhanced tumor cell migration (9\% more) in highly metastatic tumor cells MAT-LyLu but did not modify cell migration in non-metastatic tumor cells (AT-2), as was the case with our cell lines [64]. In this context, more studies are needed to study the modulation of cell migration of our anemone compounds. 


\subsubsection{Multicellular Tumor Spheroids Antitumor Assay}

To determine the effect of our homogenates on a 3D model that mimics primary tumors, we carried out an assay with MTSs which have (as actual in vivo tumors do) a gradient of nutrients, oxygen, etc. [65,66]. As shown in Figure 8A, MTSs from MC38 showed dose-dependent cell death after treatment with both HOMG W and HOMG $\mathrm{W} / \mathrm{O}$ in comparison with controls. However, HOMG W/O induced a greater volume and proliferation decrease than HOMG $\mathrm{W}$ after $72 \mathrm{~h}$ of exposure. The most significant differences between both samples were detected at $48 \mathrm{~h}$ using a $4 \times \mathrm{IC}_{50}$ concentration, and at $72 \mathrm{~h}$ MTS became more homogeneous in volume but there were significant differences in the MTS treated with HOMG W/O at $\mathrm{IC}_{50}, 2 \times \mathrm{IC}_{50}$ and $4 \times \mathrm{IC}_{50}(p<0.05)$ (Figure 8A,C and Figure S6).

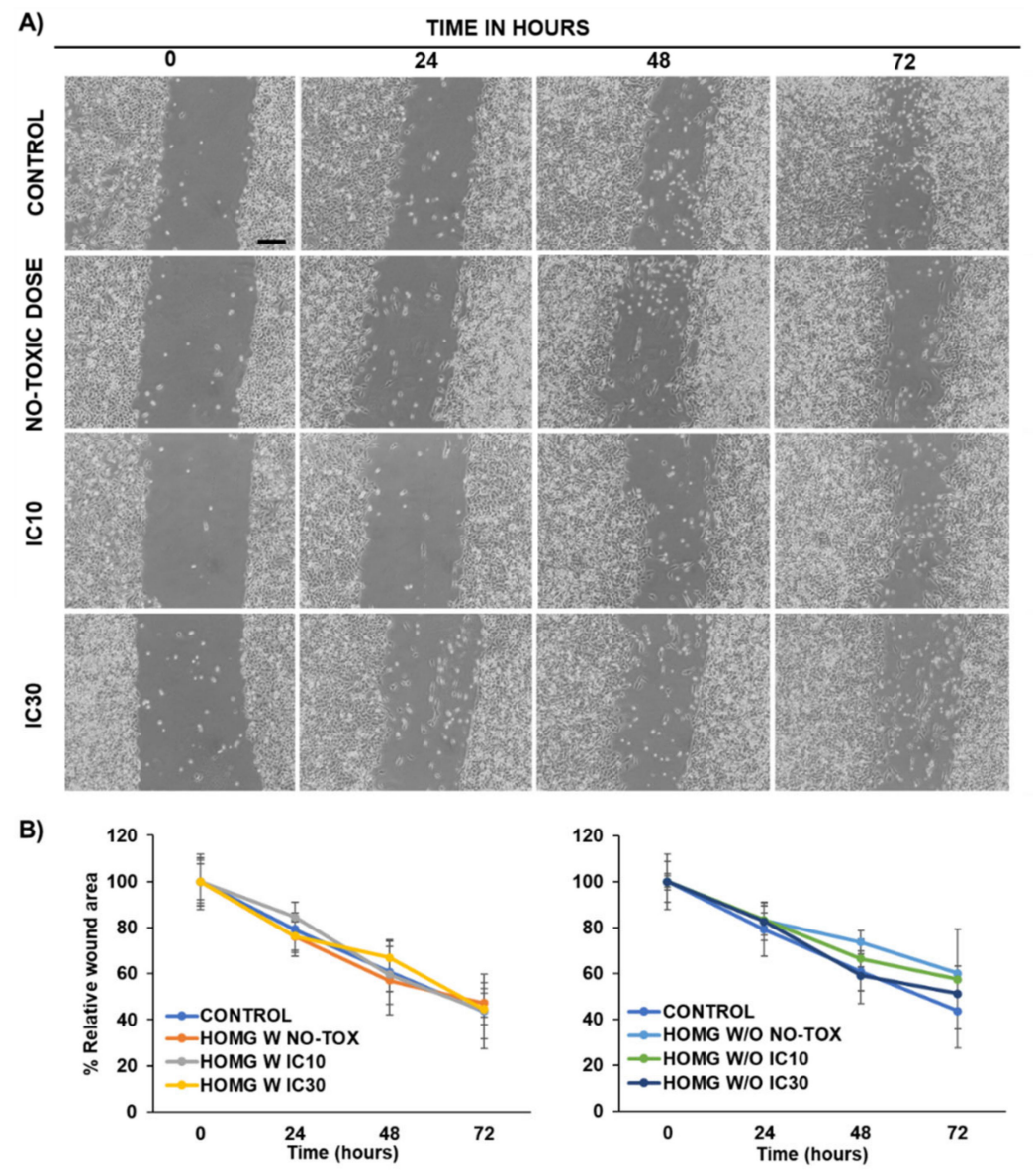

Figure 7. Wound healing assay of the crude homogenates (HOMG) on the T84 human colon cancer cell line. (A) Light microscopy images of T84 cells exposed to a non-toxic dose, $\mathrm{IC}_{10}$ and $\mathrm{IC}_{30}$ of crude HOMG with (W) symbiont for 0 to $72 \mathrm{~h}$ after making a wound with a pipette tip. The images were taken at $4 \times$ magnification (scale bar $=200 \mu \mathrm{m}$ ). (B) Percentage of relative wound area of T84 cells exposed to the crude HOMG W and HOMG W/O relative to the time $0 \mathrm{~h}(100 \%)$. Data are represented as the mean \pm standard deviation of triplicate cultures. 


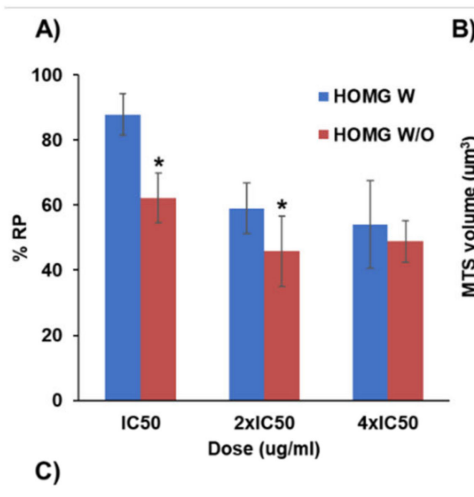

B) $\times 10^{7}$
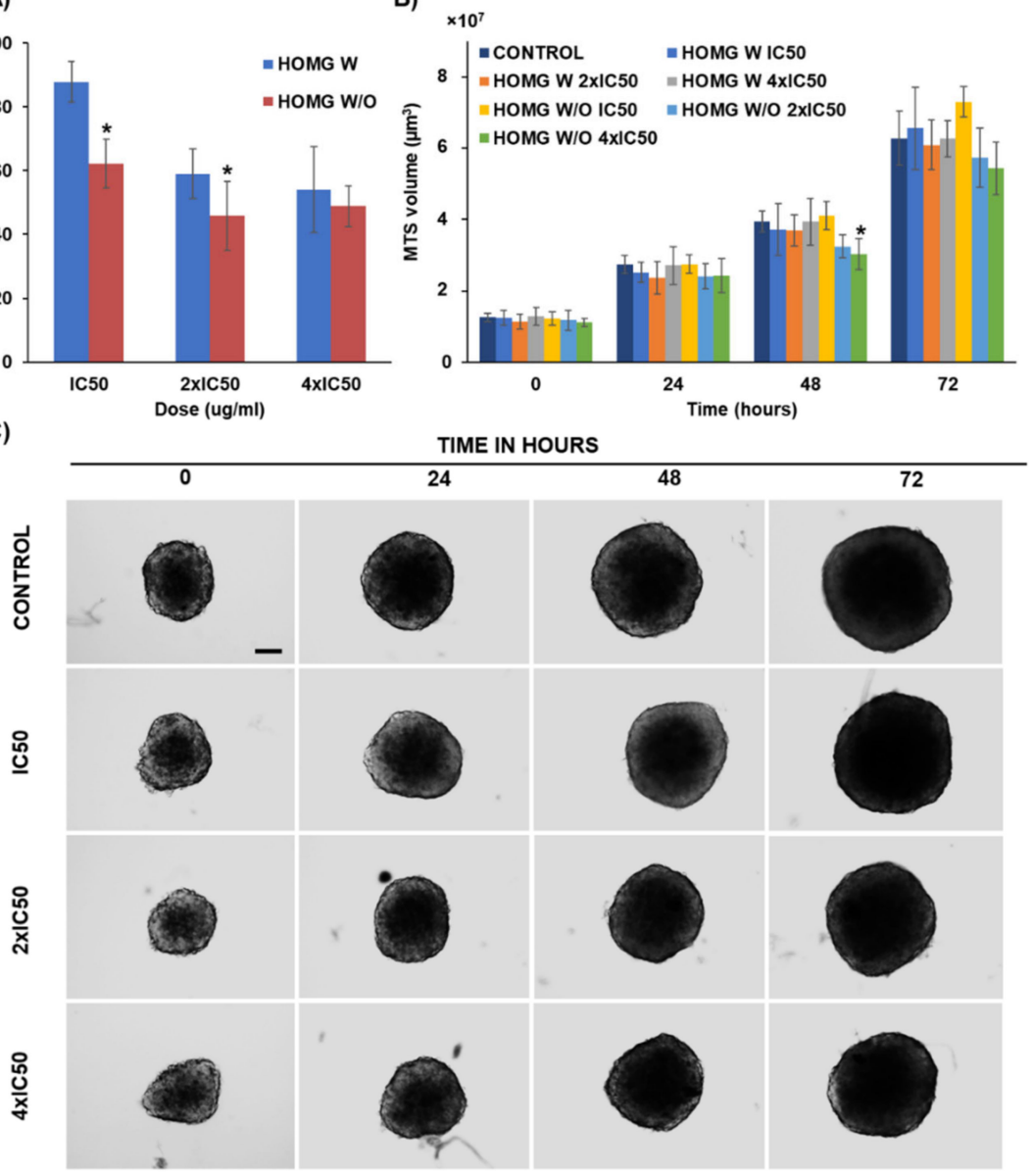

Figure 8. Multicellular tumor spheroids (MTS) from MC38 treated with the crude homogenates (HOMG). (A) Proliferation assay with CCK8 on MTS treated for $72 \mathrm{~h}$ with HOMG with (W) and without $(\mathrm{W} / \mathrm{O})$ symbiont at different doses $\left(\mathrm{IC}_{50}, 2 \times \mathrm{IC}_{50}\right.$ and $\left.4 \times \mathrm{IC}_{50}\right)$. (B) MTS volume measured at different times of exposure from the beginning of treatment $(0,24,48$ and $72 \mathrm{~h})$. Data are represented as the mean \pm standard deviation of octuplicate cultures. (C) Light microscopy images of the MTS treated with the crude homogenate without symbiont (HOMG W/O). The images were taken at $10 \times$ magnification (scale bar $=100 \mu \mathrm{m})$. The symbol * indicates significant differences between crude homogenates with $(\mathrm{W})$ and without $(\mathrm{W} / \mathrm{O})$ symbiont.

\section{Conclusions}

Analysis of the marine invertebrate Anemonia sulcata showed a proximate composition with high EPA content, especially in the anemone W/O its symbiont. The simulated digestion of the crude homogenates revealed that more than half of the digested products were potentially dialyzable, although a considerable reduction in their biological properties was detected. Accordingly, the crude homogenates without digestion were tested in cultured cells, in which HOMG W/O demonstrated high antioxidant activity. Furthermore, these crude homogenates also showed an antitumor effect on CRC cells cultured in monolayer and MTS. This antiproliferative effect could be induced by the bleaching process. Therefore, our preliminary results suggest that Anemonia sulcata subjected to the bleaching process has a greater antioxidant and antitumor potential than the normal anemone and may be a source of antitumor and antioxidant compounds with nutraceutical applications that could be useful in the treatment and prevention of CRC. Therefore, these extracts could be used in a future as a complement in a diet for CRC chemoprevention, but they should be protected to avoid loss of antioxidant and antitumor thought the digestion process. If the extracts show positive results in vivo, they could be a good complement (orally) for the chemotherapeutic treatment of CRC. In addition, due to their composition in polyunsatu- 
rated fatty acids, the consumption of these organisms also provides elements for a healthy diet, which is related to a lower CRC rate.

Supplementary Materials: The following are available online at https://www.mdpi.com/2079 $-7737 / 10 / 2 / 134 / s 1$, Figure S1. Antiproliferative activity of the ethanolic extracts in colon cells. Figure S2. Antiproliferative activity of the protein hydrolysates on colon cells. Figure S3. Effect of high temperatures and freeze-thaw cycles on the antiproliferative activity of the crude homogenates (HOMG) on the T84 human colon cancer cell line. Figure S4. Antiproliferative activity of the digestion products from the crude homogenates on the T84 cell line. Figure S5. Wound healing assay of the crude homogenates (HOMG) on the T84 human colon cancer cell line. Figure S6. Multicellular tumor spheroids (MTS) from MC38 treated with the crude homogenates. Table S1. $\mathrm{IC}_{50}$ value of colon cells treated with the ethanolic extracts (EXTOH) obtained from Anemonia sulcata with (W) and without (W/O) its symbiont.

Author Contributions: Conceptualization, J.P., J.M.P. and C.M. (Consolación Melguizo); methodology, L.C., M.P., R.M. and C.M. (Cristina Mesas); validation, M.G. and G.P.; formal analysis, M.G. and G.P.; investigation, L.C., M.P., R.M. and C.M. (Cristina Mesas); data curation, M.G. and G.P.; writing—original draft preparation, L.C., M.P. and R.M.; writing—review and editing, J.P., J.M.P. and C.M. (Consolación Melguizo); supervision, J.P. and J.M.P.; and funding acquisition, L.C. All authors have read and agreed to the published version of the manuscript.

Funding: This research was funded by the International Excellence Campus of the Sea (CEI-MAR) through the Projects CEIJ-007 and CEIJ-0012.

Institutional Review Board Statement: Not applicable.

Informed Consent Statement: Not applicable.

Data Availability Statement: Not applicable.

Conflicts of Interest: The authors declare no conflict of interest.

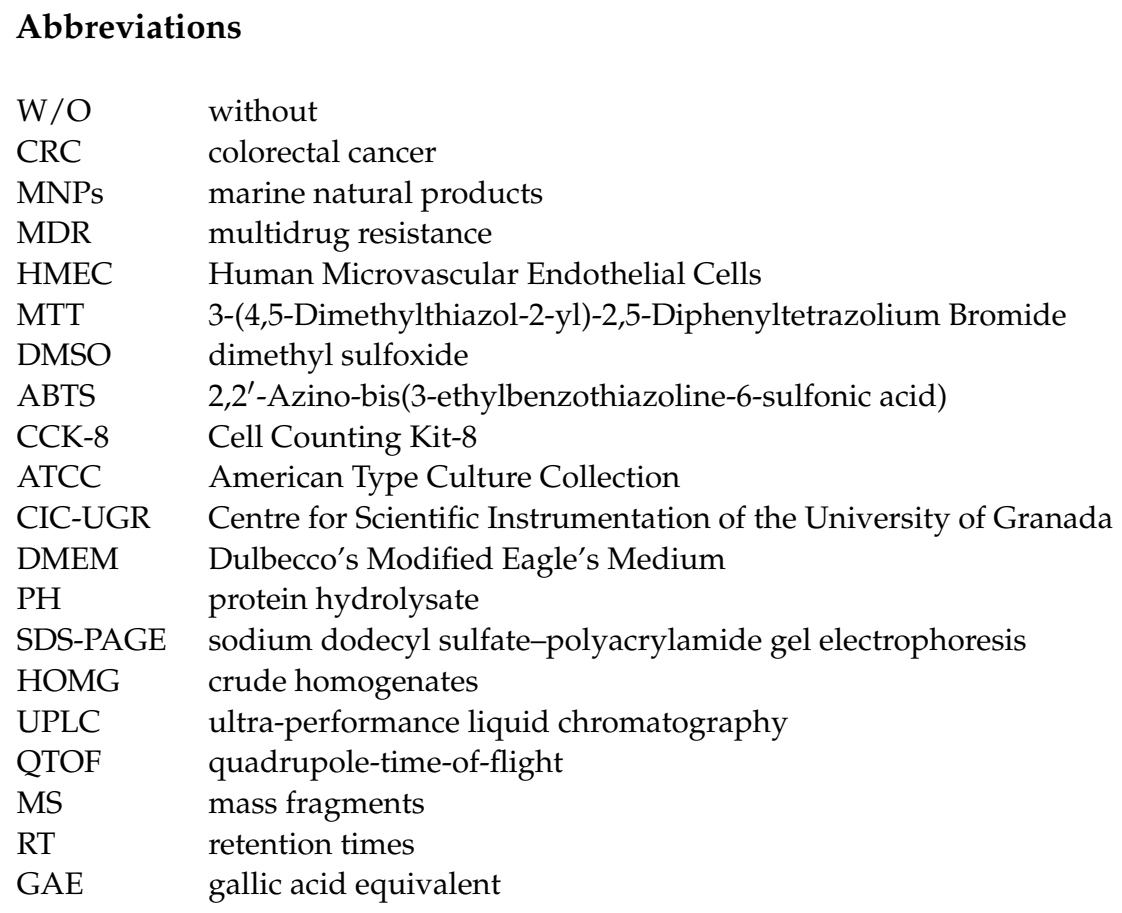




$\begin{array}{ll}\text { \%RP } & \text { relative proliferation } \\ \text { ETOH } & \begin{array}{l}\text { ethanolic extracts } \\ \text { half-maximal inhibitory concentration }\end{array} \\ \text { IC }_{50} & \begin{array}{l}\text { multicellular tumor spheroids } \\ \text { MTS }\end{array} \\ \text { SD } & \text { standard deviation } \\ \text { PUFA } & \text { polyunsaturated fatty acids } \\ \text { SFA } & \text { saturated fatty acids } \\ \text { EPA } & 5,8,11,14,17-\text {-eicosapentaenoic acid } \\ \text { DHA } & \text { cis-4,7,10,13,16,19-docosahexaenoic acid } \\ \text { MW } & \text { molecular weight } \\ \text { DIAL } & \text { dialyzed } \\ \text { RET } & \text { retained } \\ \text { ROS } & \text { reactive oxygen species } \\ \text { FITC } & \text { fluorescein }\end{array}$

\section{References}

1. Carroll, A.R.; Copp, B.R.; Davis, R.A.; Keyzers, R.A.; Prinsep, M.R. Marine natural products. Nat. Prod. Rep. 2020, 37, 175-223. [CrossRef] [PubMed]

2. Nweze, J.A.; Mbaoji, F.N.; Huang, G.; Li, Y.; Yang, L.; Zhang, Y.; Huang, S.; Pan, L.; Yang, D. Antibiotics development and the potentials of marine-derived compounds to stem the tide of multidrug-resistant pathogenic Bacteria, Fungi, and Protozoa. Mar. Drugs 2020, 18, 145. [CrossRef] [PubMed]

3. Shin, H.J. Natural Products from Marine Fungi. Mar. Drugs 2020, 18, 230. [CrossRef] [PubMed]

4. Souza, C.R.M.; Bezerra, W.P.; Souto, J.T. Marine alkaloids with anti-inflammatory activity: Current knowledge and future perspectives. Mar. Drugs 2020, 18, 147. [CrossRef] [PubMed]

5. Stien, D. Marine microbial diversity as a source of bioactive natural products. Mar. Drugs 2020, 18, 215. [CrossRef]

6. Etman, S.M.; Elnaggar, Y.S.R.; Abdallah, O.Y. Fucoidan, a natural biopolymer in cancer combating: From edible algae to nanocarrier tailoring. Int. J. Biol. Macromol. 2020, 147, 799-808. [CrossRef] [PubMed]

7. Hsu, H.-Y.; Hwang, P.-A. Clinical applications of fucoidan in translational medicine for adjuvant cancer therapy. Clin. Transl. Med. 2019, 8, 1-18. [CrossRef]

8. Khalifa, S.A.M.; Elias, N.; Farag, M.A.; Chen, L.; Saeed, A.; Hegazy, M.-E.F.; Moustafa, M.S.; Abd El-Wahed, A.; Al-Mousawi, S.M.; Musharraf, S.G.; et al. Marine natural products: A source of novel anticancer drugs. Mar. Drugs 2019, 17, 491. [CrossRef]

9. International Agency for Research on Cancer. World Health Organization Global Cancer Observatory. Available online: https: / /gco.iarc.fr / (accessed on 17 June 2019).

10. Ruiz-Torres, V.; Rodríguez-Pérez, C.; Herranz-López, M.; Martín-García, B.; Gómez-Caravaca, A.-M.; Arráez-Román, D.; SeguraCarretero, A.; Barrajón-Catalán, E.; Micol, V. Marine invertebrate extracts induce colon cancer cell death via ROS-mediated DNA oxidative damage and mitochondrial impairment. Biomolecules 2019, 9, 771. [CrossRef] [PubMed]

11. Jimenez, P.C.; Wilke, D.V.; Branco, P.C.; Bauermeister, A.; Rezende-Teixeira, P.; Gaudêncio, S.P.; Costa-Lotufo, L.V. Enriching Cancer Pharmacology with drugs of marine origin. Br. J. Pharmacol. 2020, 177, 3-27. [CrossRef]

12. Kumar, M.S.; Adki, K.M. Marine Natural products for multi-targeted cancer treatment: A future insight. Biomed. Pharmacother. 2018, 105, 233-245. [CrossRef]

13. Saadaoui, I.; Rasheed, R.; Abdulrahman, N.; Bounnit, T.; Cherif, M.; Al Jabri, H.; Mraiche, F. Algae-derived bioactive compounds with anti-lung cancer potential. Mar. Drugs 2020, 18, 197. [CrossRef]

14. Wali, A.F.; Majid, S.; Rasool, S.; Shehada, S.B.; Abdulkareem, S.K.; Firdous, A.; Beigh, S.; Shakeel, S.; Mushtaq, S.; Akbar, I.; et al. Natural products against cancer: Review on phytochemicals from marine sources in preventing cancer. Saudi Pharm. J. 2019, 27, 767-777. [CrossRef] [PubMed]

15. Cheng, C.; Othman, E.M.; Reimer, A.; Grüne, M.; Kozjak-Pavlovic, V.; Stopper, H.; Hentschel, U.; Abdelmohsen, U.R. Ageloline a, new antioxidant and antichlamydial quinolone from the marine sponge-derived bacterium Streptomyces Sp. SBT345. Tetrahedron Lett. 2016, 57, 2786-2789. [CrossRef]

16. Jiménez-Escrig, A.; Gómez-Ordóñez, E.; Rupérez, P. Chapter 26-Seaweed as a source of novel nutraceuticals: Sulfated polysaccharides and peptides. In Advances in Food and Nutrition Research; Kim, S.-K., Ed.; Marine Medicinal Foods; Academic Press: Cambridge, MA, USA, 2011; Volume 64, pp. 325-337.

17. Jin, Q.; Yu, H.; Li, P. The evaluation and utilization of marine-derived bioactive compounds with anti-obesity effect. Curr. Med. Chem. 2018, 25, 861-878. [CrossRef] [PubMed]

18. Lordan, S.; Ross, R.P.; Stanton, C. Marine bioactives as functional food ingredients: Potential to reduce the incidence of chronic diseases. Mar. Drugs 2011, 9, 1056-1100. [CrossRef]

19. Matos, J.; Cardoso, C.; Bandarra, N.M.; Afonso, C. Microalgae as healthy ingredients for functional food: A review. Food Funct. 2017, 8, 2672-2685. [CrossRef] [PubMed]

20. Lewis Ames, C. Medusa: A review of an ancient cnidarian body form. Results Probl. Cell Differ. 2018, 65, 105-136. [PubMed] 
21. Pejin, B.; Mojovic, M.; Savic, A.G. Novel and highly potent antitumour natural products from cnidarians of marine origin. Nat. Prod. Res. 2014, 28, 2237-2244. [CrossRef]

22. Rocha, J.; Peixe, L.; Gomes, N.C.M.; Calado, R. Cnidarians as a source of new marine bioactive compounds-An overview of the last decade and future steps for bioprospecting. Mar. Drugs 2011, 9, 1860-1886. [CrossRef]

23. Ruppert, E.E.; Barnes, R.D. Invertebrate Zoology, 6th ed.; Saunders College Publishing: Orlando, FL, USA, 1993 ; p. 1056.

24. Silva, T.C.; de Andrade, P.B.; Paiva-Martins, F.; Valentão, P.; Pereira, D.M. In vitro anti-inflammatory and cytotoxic effects of aqueous extracts from the edible sea anemones Anemonia sulcata and Actinia equina. Int. J. Mol. Sci. 2017, 18, 653. [CrossRef]

25. Frazão, B.; Vasconcelos, V.; Antunes, A. Sea anemone (Cnidaria, Anthozoa, Actiniaria) toxins: An overview. Mar. Drugs 2012, 10, 1812-1851. [CrossRef]

26. Schweitz, H.; Vincent, J.P.; Barhanin, J.; Frelin, C.; Linden, G.; Hugues, M.; Lazdunski, M. Purification and pharmacological properties of eight sea anemone toxins from Anemonia sulcata, Anthopleura xanthogrammica, Stoichactis giganteus, and Actinodendron plumosum. Biochemistry 1981, 20, 5245-5252. [CrossRef]

27. Smith, H.G. The significance of the relationship between actinians and zooxanthellae. J. Exp. Biol. 1939, 16, $334-345$.

28. Revel, J.; Massi, L.; Mehiri, M.; Boutoute, M.; Mayzaud, P.; Capron, L.; Sabourault, C. Differential distribution of lipids in epidermis, gastrodermis and hosted symbiodinium in the sea anemone Anemonia viridis. Comp. Biochem. Physiol. A Mol. Integr. Physiol. 2016, 191, 140-151. [CrossRef] [PubMed]

29. Bulati, M.; Longo, A.; Masullo, T.; Vlah, S.; Bennici, C.; Bonura, A.; Salamone, M.; Tagliavia, M.; Nicosia, A.; Mazzola, S.; et al. Partially purified extracts of sea anemone Anemonia viridis affect the growth and viability of selected tumour cell lines. BioMed Res. Int. 2016, 2016, 1-12. [CrossRef] [PubMed]

30. Loret, E.P.; Luis, J.; Nuccio, C.; Villard, C.; Mansuelle, P.; Lebrun, R.; Villard, P.H. A low molecular weight protein from the sea anemone Anemonia viridis with an anti-angiogenic activity. Mar. Drugs 2018, 16, 134. [CrossRef] [PubMed]

31. Merle, P.-L.; Sabourault, C.; Richier, S.; Allemand, D.; Furla, P. Catalase characterization and implication in bleaching of a symbiotic sea anemone. Free Radic. Biol. Med. 2007, 42, 236-246. [CrossRef]

32. Pey, A.; Zamoum, T.; Christen, R.; Merle, P.-L.; Furla, P. Characterization of glutathione peroxidase diversity in the symbiotic sea anemone Anemonia viridis. Biochimie 2017, 132, 94-101. [CrossRef] [PubMed]

33. Martínez, R.; Kapravelou, G.; Donaire, A.; Lopez-Chaves, C.; Arrebola, F.; Galisteo, M.; Cantarero, S.; Aranda, P.; Porres, J.M.; López-Jurado, M. Effects of a combined intervention with a lentil protein hydrolysate and a mixed training protocol on the lipid metabolism and hepatic markers of NAFLD in Zucker rats. Food Funct. 2018, 9, 830-850. [CrossRef] [PubMed]

34. Kapravelou, G.; Martínez, R.; Andrade, A.M.; Chaves, C.L.; López-Jurado, M.; Aranda, P.; Arrebola, F.; Cañizares, F.J.; Galisteo, M.; Porres, J.M. Improvement of the antioxidant and hypolipidaemic effects of cowpea flours (Vigna Unguiculata) by fermentation: Results of in vitro and in vivo experiments. J. Sci. Food Agric. 2015, 95, 1207-1216. [CrossRef] [PubMed]

35. Porres, J.M.; Aranda, P.; López-Jurado, M.; Urbano, G. Nutritional potential of raw and free alpha-galactosides lupin (Lupinus albus Var. multolupa) seed flours. Effect of phytase treatment on nitrogen and mineral dialyzability. J. Agric. Food Chem. 2005, 53, 3088-3094. [CrossRef]

36. Dewanto, V.; Wu, X.; Adom, K.K.; Liu, R.H. Thermal processing enhances the nutritional value of tomatoes by increasing total antioxidant activity. J. Agric. Food Chem. 2002, 50, 3010-3014. [CrossRef] [PubMed]

37. Miller, N.J.; Rice-Evans, C.; Davies, M.J.; Gopinathan, V.; Milner, A. A novel method for measuring antioxidant capacity and its application to monitoring the antioxidant status in premature neonates. Clin. Sci. (Lond.) 1993, 84, 407-412. [CrossRef] [PubMed]

38. Nkondjock, A.; Shatenstein, B.; Maisonneuve, P.; Ghadirian, P. Specific Fatty acids and human colorectal cancer: An overview. Cancer Detect. Prev. 2003, 27, 55-66. [CrossRef]

39. Sellem, L.; Srour, B.; Guéraud, F.; Pierre, F.; Kesse-Guyot, E.; Fiolet, T.; Lavalette, C.; Egnell, M.; Latino-Martel, P.; Fassier, P.; et al. Saturated, mono- and polyunsaturated fatty acid intake and cancer risk: Results from the French prospective cohort Nutrinet-Santé. Eur. J. Nutr. 2019, 58, 1515-1527. [CrossRef] [PubMed]

40. Irún, P.; Lanas, A.; Piazuelo, E. Omega-3 polyunsaturated fatty acids and their bioactive metabolites in gastrointestinal malignancies related to unresolved inflammation. A review. Front. Pharmacol. 2019, 10, 852. [CrossRef] [PubMed]

41. Losantos, R.; Churio, M.S.; Sampedro, D. Computational exploration of the photoprotective potential of gadusol. ChemistryOpen 2015, 4, 155-160. [CrossRef]

42. D'Auria, M.V.; Riccio, R.; Minale, L. Ophioxanthin, a new marine carototenoid sulphate from the ophiuroid Ophioderma longicaudum. Tetrahedron Lett. 1985, 26, 1871-1872. [CrossRef]

43. Milani, A.; Basirnejad, M.; Shahbazi, S.; Bolhassani, A. Carotenoids: Biochemistry, pharmacology and treatment. Br. J. Pharmacol. 2017, 174, 1290-1324. [CrossRef]

44. Dark, G.G.; Hill, S.A.; Prise, V.E.; Tozer, G.M.; Pettit, G.R.; Chaplin, D.J. Combretastatin A-4, an agent that displays potent and selective toxicity toward tumor vasculature. Cancer Res. 1997, 57, 1829-1834. [PubMed]

45. Shi, Y.-W.; Yuan, W.; Wang, X.; Gong, J.; Zhu, S.-X.; Chai, L.-L.; Qi, J.-L.; Qin, Y.-Y.; Gao, Y.; Zhou, Y.-L.; et al. Combretastatin A-4 efficiently inhibits angiogenesis and induces neuronal apoptosis in zebrafish. Sci. Rep. 2016, 6, 30189. [CrossRef] [PubMed]

46. Shanab, S.M.M.; Hafez, R.M.; Fouad, A.S. A Review on algae and plants as potential source of arachidonic acid. J. Adv. Res. 2018, 11,3-13. [CrossRef] [PubMed]

47. Sun, R.; Zhang, H.-M.; Chen, B.-A. Anticancer activity and underlying mechanism of neogambogic acid. Chin. J. Nat. Med. 2018, 16, 641-643. [CrossRef] 
48. Vieira-Júnior, G.M.; Dutra, L.A.; Ferreira, P.M.P.; de Moraes, M.O.; Costa Lotufo, L.V.; Pessoa, C.D.Ó.; Torres, R.B.; Boralle, N.; Bolzani, V.d.S.; Cavalheiro, A.J. Cytotoxic clerodane diterpenes from Casearia rupestris. J. Nat. Prod. 2011, 74, 776-781. [CrossRef]

49. Horiuchi, T.; Fujiki, H.; Suganuma, M.; Hakii, H.; Nakayasu, M.; Hitotsuyanagi, Y.; Aimi, N.; Sakai, S.; Endo, Y.; Shudo, K. Studies on olivoretins indicate a requirement for a free hydroxyl group for teleocidin B activity. Gan 1984, 75, 837-840. [PubMed]

50. Cheung, R.C.F.; Ng, T.B.; Wong, J.H. Marine peptides: Bioactivities and applications. Mar. Drugs 2015, 13, 4006-4043. [CrossRef]

51. Ryan, J.T.; Ross, R.P.; Bolton, D.; Fitzgerald, G.F.; Stanton, C. Bioactive peptides from muscle sources: Meat and fish. Nutrients 2011, 3, 765-791. [CrossRef]

52. Corona, G.; Coman, M.M.; Guo, Y.; Hotchkiss, S.; Gill, C.; Yaqoob, P.; Spencer, J.P.E.; Rowland, I. Effect of simulated gastrointestinal digestion and fermentation on polyphenolic content and bioactivity of brown seaweed phlorotannin-rich extracts. Mol. Nutr. Food Res. 2017, 61, 1700223. [CrossRef]

53. Ydjedd, S.; Bouriche, S.; López-Nicolás, R.; Sánchez-Moya, T.; Frontela-Saseta, C.; Ros-Berruezo, G.; Rezgui, F.; Louaileche, H.; Kati, D.-E. Effect of in vitro gastrointestinal digestion on encapsulated and nonencapsulated phenolic compounds of carob (Ceratonia siliqua L.) pulp extracts and their antioxidant capacity. J. Agric. Food Chem. 2017, 65, 827-835. [CrossRef]

54. Sun, Y.; Li, S.; Zeng, F.; Qi, J.; Qin, W.; Tan, C.; Luo, Q.; Wu, D.; Zhang, Q.; Lin, D.; et al. Functional components, antioxidant activity and hypoglycemic ability following simulated gastro-intestinal digestion of pigments from walnut brown shell and green husk. Antioxidants 2019, 8, 573. [CrossRef] [PubMed]

55. Valdés, L.; Cuervo, A.; Salazar, N.; Ruas-Madiedo, P.; Gueimonde, M.; González, S. The relationship between phenolic compounds from diet and microbiota: Impact on human health. Food Funct. 2015, 6, 2424-2439. [CrossRef] [PubMed]

56. Bessell-Browne, P.; Negri, A.P.; Fisher, R.; Clode, P.L.; Jones, R. Impacts of light limitation on corals and crustose coralline algae. Sci. Rep. 2017, 7, 1-12. [CrossRef] [PubMed]

57. Roberty, S.; Furla, P.; Plumier, J.-C. Differential antioxidant response between two symbiodinium species from contrasting environments. Plant Cell Environ. 2016, 39, 2713-2724. [CrossRef]

58. Wietheger, A.; Starzak, D.E.; Gould, K.S.; Davy, S.K. Differential ROS generation in response to stress in Symbiodinium spp. Biol. Bull. 2018, 234, 11-21. [CrossRef]

59. Hoepner, C.M.; Abbott, C.A.; Burke da Silva, K. The ecological importance of toxicity: Sea anemones maintain toxic defence when bleached. Toxins 2019, 11, 266. [CrossRef] [PubMed]

60. Ramezanpour, M.; da Silva, K.B.; Sanderson, B.J.S. The effect of sea anemone (H. magnifica) venom on two human breast cancer lines: Death by apoptosis. Cytotechnology 2014, 66, 845-852. [CrossRef]

61. Ramezanpour, M.; da Silva, K.B.; Sanderson, B.J.S. Venom present in sea anemone (Heteractis magnifica) induces apoptosis in non-small-cell lung cancer A549 cells through activation of mitochondria-mediated pathway. Biotechnol. Lett. 2014, 36, 489-495. [CrossRef] [PubMed]

62. Su, S.; Xu, H.; Chen, X.; Qiao, G.; Farooqi, A.A.; Tian, Y.; Yuan, R.; Liu, X.; Li, C.; Li, X.; et al. CS5931, A novel marine polypeptide, inhibits migration and invasion of cancer cells via interacting with enolase 1. Recent Patents Anticancer Drug Discov. 2018, 13, 360-367. [CrossRef]

63. Mudit, M.; El Sayed, K.A. Cancer control potential of marine natural product scaffolds through inhibition of tumor cell migration and invasion. Drug Discov. Today 2016, 21, 1745-1760. [CrossRef]

64. Fraser, S.P.; Salvador, V.; Manning, E.A.; Mizal, J.; Altun, S.; Raza, M.; Berridge, R.J.; Djamgoz, M.B.A. Contribution of functional voltage-gated $\mathrm{Na}+$ channel expression to cell behaviors involved in the metastatic cascade in rat prostate cancer: I. lateral motility. J. Cell. Physiol. 2003, 195, 479-487. [CrossRef] [PubMed]

65. Riffle, S.; Pandey, R.N.; Albert, M.; Hegde, R.S. Linking hypoxia, DNA damage and proliferation in multicellular tumor spheroids. BMC Cancer 2017, 17, 338. [CrossRef] [PubMed]

66. Rodrigues, T.; Kundu, B.; Silva-Correia, J.; Kundu, S.C.; Oliveira, J.M.; Reis, R.L.; Correlo, V.M. Emerging tumor spheroids technologies for 3D in vitro cancer modeling. Pharmacol. Ther. 2018, 184, 201-211. [CrossRef] [PubMed] 